\title{
Abrupt transition from fractional crystallization to magma mixing at Gorely volcano (Kamchatka) after caldera collapse
}

\author{
Maxim Gavrilenko ${ }^{1,2}$ • Alexey Ozerov ${ }^{2}$ Philip R. Kyle ${ }^{3}$ - Michael J. Carr ${ }^{1}$ • \\ Alex Nikulin ${ }^{4} \cdot$ Christopher Vidito $^{1} \cdot$ Leonid Danyushevsky $^{5}$
}

Received: 29 September 2015 / Accepted: 26 May 2016 /Published online: 7 June 2016

(C) Springer-Verlag Berlin Heidelberg 2016

\begin{abstract}
A series of large caldera-forming eruptions (361$38 \mathrm{ka}$ ) transformed Gorely volcano, southern Kamchatka Peninsula, from a shield-type system dominated by fractional crystallization processes to a composite volcanic center, exhibiting geochemical evidence of magma mixing. Old Gorely, an early shield volcano (700-361 ka), was followed by Young Gorely eruptions. Calc-alkaline high magnesium basalt to rhyolite lavas have been erupted from Gorely volcano since the Pleistocene. Fractional crystallization dominated evolution of the Old Gorely magmas, whereas magma mixing is more prominent in the Young Gorely eruptive products. The role of rechargeevacuation processes in Gorely magma evolution is negligible (a closed magmatic system); however, crustal rock assimilation plays a significant role for the evolved magmas. Most Gorely magmas differentiate in a shallow magmatic system at pressures
\end{abstract}

Editorial responsibility: M.L. Coombs

Electronic supplementary material The online version of this article (doi:10.1007/s00445-016-1038-z) contains supplementary material, which is available to authorized users.

Maxim Gavrilenko

max.gavrilenko@gmail.com

1 Department of Earth and Planetary Sciences, Rutgers University, 610 Taylor Rd., Piscataway, NJ 08854, USA

2 Institute of Volcanology and Seismology, Russia 683006 Petropavlovsk-KamchatskyPiip blvd, 9

3 Department of Earth and Environmental Science, New Mexico Institute of Mining and Technology, Socorro, NM 87801, USA

4 Department of Geological Sciences and Environmental Studies, Binghamton University, The State University of New York, 4400 Vestal Parkway East, Binghamton, NY 13902, USA

5 CODES and Earth Sciences, University of Tasmania, Hobart, Australia 7001 up to $300 \mathrm{MPa}, \sim 3 \mathrm{wt} \% \mathrm{H}_{2} \mathrm{O}$, and oxygen fugacity of $\sim \mathrm{QFM}+$ $1.5 \mathrm{log}$ units. Magma temperatures of $1123-1218^{\circ} \mathrm{C}$ were measured using aluminum distribution between olivine and spinel in Old and Young Gorely basalts. The crystallization sequence of major minerals for Old Gorely was as follows: olivine and spinel $(\mathrm{Ol}+\mathrm{Sp}$ ) for mafic compositions (more than $5 \mathrm{wt} \%$ of $\mathrm{MgO}$ ); clinopyroxene and plagioclase crystallized at $\sim 5 \mathrm{wt} \%$ of $\mathrm{MgO}$ $(\mathrm{Ol}+\mathrm{Cpx}+\mathrm{Plag})$ and magnetite at $\sim 3.5 \mathrm{wt} \%$ of $\mathrm{MgO}(\mathrm{Ol}+$ $\mathrm{Cpx}+$ Plag $+\mathrm{Mt})$. We show that the shallow magma chamber evolution of Old Gorely occurs under conditions of decompression and degassing. We find that the caldera-forming eruption(s) modified the magma plumbing geometry. This led to a change in the dominant magma evolution process from fractional crystallization to magma mixing. We further suggest that disruption of the magma chamber and accompanying change in differentiation process have the potential to transform a shield volcanic system to that of composite cone on a global scale.

Keywords Magma mixing · Fractional crystallization · Magma plumbing system reorganization · Caldera $\cdot$ Gorely volcano $\cdot$ Kamchatka $\cdot$ Volcano morphology

\section{Introduction}

A major problem in understanding magma generation in island arcs is defining the melt source conditions and understanding the chemical evolution of the melt during its ascent to the Earth's surface. Primary magma generation in arc environments results from partial melting of the mantle wedge above the subducting slab. The partial melting is induced by dehydration of the subducting oceanic crust which releases fluids into the mantle wedge. Primary basaltic magmas are produced and these are parental to most calc-alkaline suites (e.g., Gill 1981; Grove et al. 2003; Arculus 2003; Rogers 
2015). As the primary magmas rise to the Earth's surface, they evolve by various processes including fractional crystallization, mixing, and assimilation.

Beneath Kamchatka, at depths of $50-70 \mathrm{~km}$, the mantle wedge is hot $\left(1245-1330{ }^{\circ} \mathrm{C}\right)$ (Portnyagin et al. 2007b). Water is the major fluid component released from the dehydrating subducting slab, but it also hosts trace amounts of other volatile elements, which often leave a signature on the resulting basalts formed during partial melting (Wallace 2005; Ruscitto et al. 2010, 2012; Plank et al. 2013). The degree of partial melting of the mantle depends mainly on P-T conditions, amount of fluid input from the slab, and proportion of mineral phases (garnet, spinel, pyroxenes, and olivine). The relative contributions of the slab components: oceanic sediment, altered oceanic crust, and mid-ocean ridge basalts are also very important. These factors, in turn, are affected by the geometry of the subduction zone. Old and cold subducted lithosphere commonly sinks faster and at a steeper angle than young and hot plate (Stern 2002).

During the ascent of melts to the Earth's surface, compositions can change significantly. Fractionation of a rising hydrous primary basaltic magmas can result in a variety of more viscous $\mathrm{SiO}_{2}$-rich magmas (Gill 1981). Fractional crystallization is the dominant chemical evolution process resulting from decompression and cooling (e.g., Grove et al. 2003). The ubiquitous existence of a shallow magma chamber usually complicates the understanding of the evolutionary process because crystallization differentiation, magma mixing, and crustal rock assimilation obscure the early phases of magma generation and evolution (e.g., DePaolo 1981; Hildreth and Moorbath 1988). Calderas are often associated with shallow magma chambers and play an important role in understanding magma differentiation processes (e.g., Branney and Acocella 2015).

The Kamchatka Peninsula (Fig. 1) is a part of the volcanic Ring of Fire around the Pacific Ocean and has more than 20 Late Pleistocene-Holocene calderas (Braitseva et al. 1995). In this work, we reconstruct the evolution in the magmatic system of Gorely volcano. The volcanic edifice experienced a series of caldera collapses (Seligman et al. 2014) and postcaldera volcanism (Selyangin and Ponomareva 1999), providing good exposures of both pre- and post-caldera lavas. We use whole-rock and mineral data to investigate changes to the Gorely magma system caused by the most recent caldera collapse at 38-40 ka. Specifically, we show that magma mixing processes increased after the caldera formation.

\section{Geological setting}

Volcanic systems in Kamchatka vary in age, productivity, and source composition. Three distinct regions of volcanism exist: the nearly extinct Sredinny Range, the active Eastern Volcanic Front (EVF), and the active Central Kamchatka Depression
(Avdeiko et al. 2007) (Fig. 1). In this paper, we focus on Late Quaternary arc volcanism of the EVF, where volcanism is driven by the contemporary subduction of the Pacific plate beneath the Kamchatka Peninsula (Gorbatov et al. 1997). EVF volcanoes are positioned $\sim 100 \mathrm{~km}$ above the subducting Pacific Plate. The general subduction azimuth beneath the EVF is $\sim 310^{\circ}$ relative to a fixed overriding plate with a $\sim 55^{\circ}$ dip of the subducting plate. The rate of subduction is estimated at $\sim 80 \mathrm{~mm} /$ year (DeMets et al. 1990; Steblov et al. 2003), and the age of the subducting plate is estimated at $\sim 80$ $90 \mathrm{Ma}$ (Gorbatov et al. 1997, Müller et al. 2008). The subduction dip angle beneath the EVF changes to $\sim 35^{\circ}$ at the northern termination of the subduction zone. This change in angle may be attributed to the thermal impact of the Meiji seamounts entering the subduction zone, possible slab tear beneath Northern Kamchatka (Levin et al. 2002; Portnyagin et al. 2007a), and may be related to an anomalous seismic structure in the mantle wedge described by Nikulin et al. (2012).

The geochemistry of the Kamchatka volcanic rocks is typical of global arc volcanism. They show enrichment in large ion lithophile elements $(\mathrm{Rb}, \mathrm{Ba}, \mathrm{K}, \mathrm{Pb}$, and $\mathrm{Sr})$ with respect to high field strength elements ( $\mathrm{Nb}, \mathrm{Zr}$, and Ti) (Volynets et al. 2000, Ishikawa et al. 2001, Avdeiko et al. 2007). However, local subduction zone structure, including height above the subducting plate, crustal thickness, and pressure and temperature variations all have the potential to impact the geochemical signature of erupted lavas (Churikova et al. 2001; Duggen et al. 2007; Portnyagin et al. 2007a, b; Volynets et al. 2010).

Gorely volcano is a large, long-lived, shield-like eruptive center, located within the south segment of the EVF (Fig. 1). It lies $\sim 15 \mathrm{~km}$ northwest of Mutnovsky volcano, which is on the volcanic front. The crustal thickness below Gorely is constrained by geophysical methods to $\sim 36-40 \mathrm{~km}$. Deep seismic survey studies estimated the thickness at $40 \mathrm{~km}$ (Bulin 1977). Gravity-based crustal thickness interpretations indicate a total crustal thickness of $\sim 36 \mathrm{~km}$ (Baboshina et al. 1984) and converted phase studies indicate a total thickness of $39 \mathrm{~km}$ (Zlobin et al. 2005). Our estimate of the crustal thickness, estimated from the lowermost extent of well-constrained crustal seismicity is $\sim 40 \mathrm{~km}$ (Fig. 1c), in good agreement with past estimates and recent estimates by Iwasaki et al. (2013).

Seismic hypocenter locations within the plate show the depth to the subducting Pacific plate beneath Gorely is 120 km (Selyangin 1993; Selyangin and Ponomareva 1999; Gorbatov et al. 1997; Gorbatov et al. 1999). Our estimate, using a high-precision catalog of seismicity reported by the Kamchatka Branch of the Geophysical Service, suggests the Pacific plate is $\sim 130 \mathrm{~km}$ beneath the Gorely volcanic center (Fig. 1c). The thickness of the mantle wedge from the downgoing top of the Pacific Slab to the base of the crust beneath Gorely is $90 \mathrm{~km}$. At Mutnovsky volcano, the top of the slab is $110 \mathrm{~km}$ deep. This implies a difference between sources for the volcanoes, which was demonstrated in Duggen et al. (2007). 

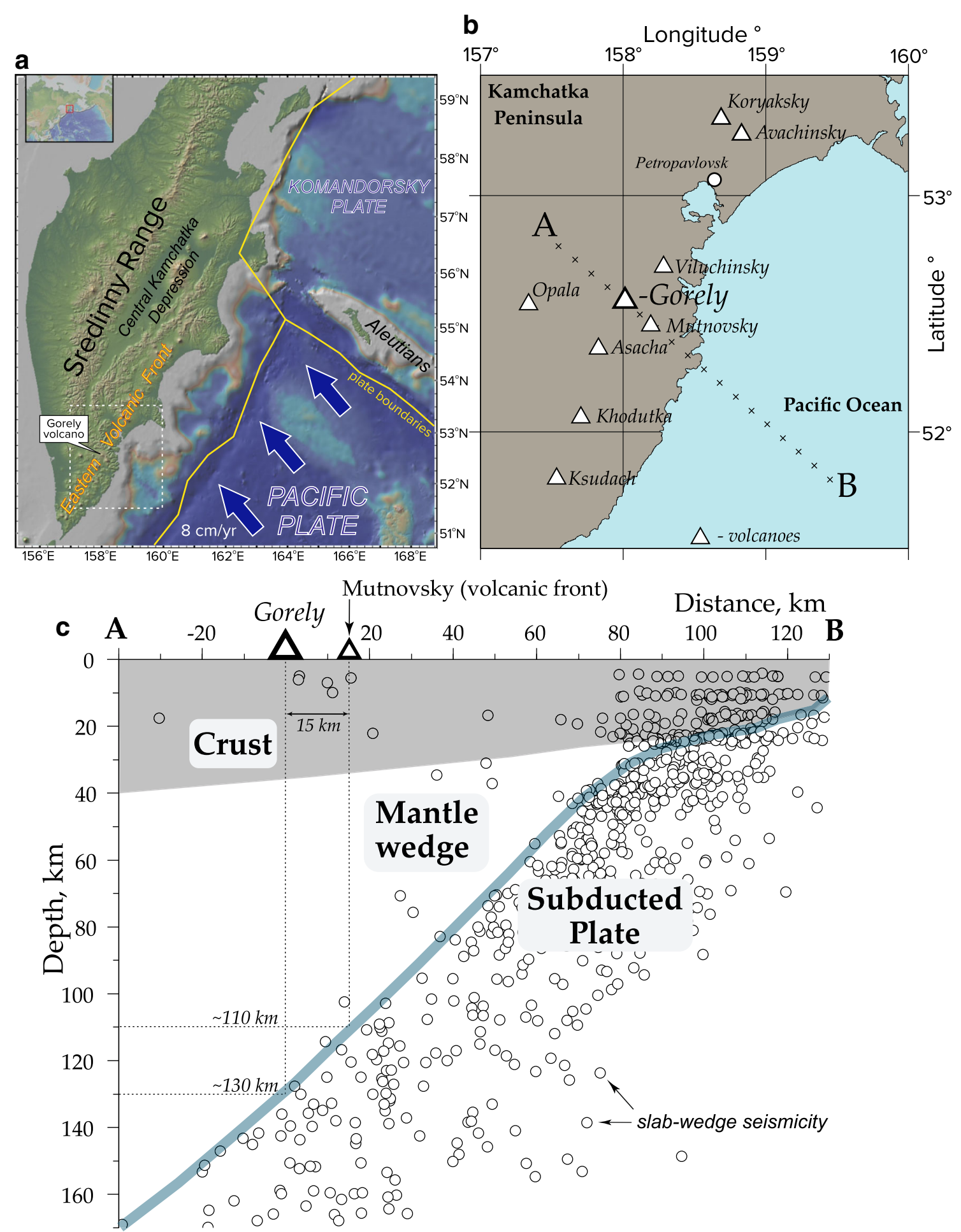

Fig. 1 a Kamchatka structural units and Gorely volcano location. The topographic base was produced in GeoMapApp (http://www.geomapapp. org), based on the Global Multi-Resolution Topography (GMRT) synthesis (Ryan et al. 2009). Plate boundaries are by Bird (2003). Arrows show the direction of Pacific plate subduction- $310^{\circ}$ (after Gorbatov et al. 1997). b Location of seismic profile $(A-B)$ with names

Gorely has a complex structure, consisting of two edifices (Kirsanov and Melekescev 1991, Selyangin and Ponomareva of surrounding volcanoes. c Seismic profile through Kamchatka subduction zone centered on Gorely volcano, showing seismic events with $\mathrm{Mw}>5.5$, as calculated and reported by the Kamchatka Branch of the Geophysical Service $(K B G S)$, drafted within a $20-\mathrm{km}$ band perpendicular to the strike of the subducting Pacific slab $\left(310^{\circ}\right)$. Crustal thickness from Iwasaki et al. 2013

1999). The oldest edifice, referred to as "Old Gorely," has a shield morphology and is $\sim 12 \times 15 \mathrm{~km}$ in size. A large caldera, 
measuring $9 \times 13 \mathrm{~km}$, is located in the center of this edifice. In the central part of the caldera, the youngest edifice, referred to as "Young Gorely", consists of three cones, forming a NorthWest striking ridge. The height of the central cone is $1829 \mathrm{~m}$. The summit contains 11 superimposed craters. Additionally, on the slopes, there are about 40 cinder cones with many lava flows (Kirsanov and Melekescev 1991).

Eruptions of Gorely were described by travelers in the nineteenth and twentieth centuries. Limited geological and volcanological reports were completed between 1930 and 1950 (Novograblenov 1932; Kulakov 1936; Zavaritsky et al. 1954; Svyatlovsky 1956; Vlodavets 1957), and more systematic geological studies started in the second half of the twentieth century (Kirsanov 1964; Kirsanov and Fedorov 1964; Kirsanov et al. 1964; Kirsanov and Ozerov 1983; Kirsanov 1985; Kirsanov and Melekescev 1991; Selyangin and Ponomareva 1999). A detailed geological map of Gorely volcano was made by Selyangin (2009). Recent geochemical and petrological studies focused on mantle wedge melting (Duggen et al. 2007), magma chamber processes (Chashchin and Martynov 2011; Chashchin et al. 2011), melt inclusions (Tolstykh et al. 2012), and silicic magma generation (Seligman et al. 2014). Gorely emerged as a volcanic center within the Old Gorely edifice in the middle Pleistocene $\left(Q_{2}\right)$ (Selyangin and Ponomareva 1999). A thick ignimbrite complex $\left(\sim 100 \mathrm{~km}^{3}\right)$ (Kirsanov and Melekescev 1991) was once believed to have been deposited during a caldera-forming eruption 38-40 ka (Selyangin and Ponomareva 1999). However, Ar-dates from different ignimbrite units suggest that there were several nested calderas ranging in age from 361 to $38 \mathrm{ka}$ (Bindeman et al. 2010; Seligman et al. 2014). Young Gorely started to emerge inside the caldera toward the end of Late Pleistocene. This edifice consists of three main cones (G1, G2, G3) that were active at different times. Thus, the contemporary Gorely volcanic center represents an evolutionary development of an older volcanic center, followed by a radical transformation of its magma-feeding system. Based on seismic velocity variations, electric conductivity, and gravity observations (Selyangin and Ponomareva 1999), Gorely currently has a large magmatic system at depths of 2 to $10 \mathrm{~km}$.

Gorely volcanic center is currently (2010-2013) in an active "gas eruption" phase (Aiuppa et al. 2012), but prior explosive eruptions (mainly gas eruptions ejecting minor amounts of volcanic ash) occurred in 1980-1981 and 1984-1986(Kirsanov and Ozerov 1983, Ivanov et al. 1988, Budnikov 1988).

\section{Analytical methods}

Gorely volcano was examined in several Institute of Volcanology and Seismology (Russia) expeditions using cross-country vehicles. We sampled as many volcanostructural complexes as possible (Fig. 2) to examine the magmatic evolution of the volcanic complex.

\section{Whole-rock analyses}

Whole-rock (WR) analyses were made by X-ray fluorescence (XRF), laser ablation inductively coupled plasma mass spectrometry (LA-ICP-MS), and inductively coupled plasma mass spectrometry (ICP-MS solution). Analyses were made at New Mexico Institute of Mining and Technology (NMT), University of Alaska Fairbanks (UAF), and University of Tasmania (UTAS).

Samples were prepared at Moscow State University (Russia), the Vernadsky Institute of Geochemistry and Analytical Chemistry (Russia), the University of Alaska Fairbanks (USA), and the University of Tasmania (Australia). Clean chips of rock material were crushed in a steel jaw crusher. For ICP-MS solution analysis, we used a hydraulic press with tungsten contact surfaces for crushing (University of Tasmania). Rock chips were ground to fine powder in an agate mill for major and trace elements analysis.

\section{$X R F$ analyses}

Whole rock geochemical analyses of major and trace elements by XRF technique were performed at NMT ( 47 samples), UAF (31 samples), and UTAS (8 samples; all data shown in Table S1). Major element concentrations were determined on fused glass discs using a Philips PW2400 (at NMT) and a Panalytical Axios (at UAF and UTAS) instruments. Trace elements were analyzed on press powder disks (at NMT) and on fused glass discs (at UAF and UTAS). International reference standards BIR-1, JB2, BHVO-1 (basalts), JA-2, AGV-1 (andesites), JR-1 (rhyolite), and JGb-1 (gabbro) were analyzed along with the samples to evaluate analytical precision and accuracy.

\section{LA-ICP-MS analyses}

Thirty-one trace elements were determined in 46 samples by Laser Ablation ICP-MS technique at the UAF laboratory (Table S2). The glass beads from XRF analyses (ultra-pure lithium borates fused with the sample powder) were used. This technique is a rapid ( $5 \mathrm{~min}$ per analysis), quantitative (low detection limits and high precision) analysis and complimented the XRF analyses (Norman et al. 1996). Measurements were made using an Agilent 7500ce instrument with UP-213 Laser Ablation System. NIST 610, 612 glasses were used for calibration and a natural standard (JB-2) to evaluate analytical precision and accuracy. Details of the analytical procedure are described by Norman et al. (1996) and Orihashi and Hirata (2003).

\section{Solution ICP-MS analyses}

Selected trace element concentrations were measured in 32 samples at the Centre of Excellence in Ore Deposits 


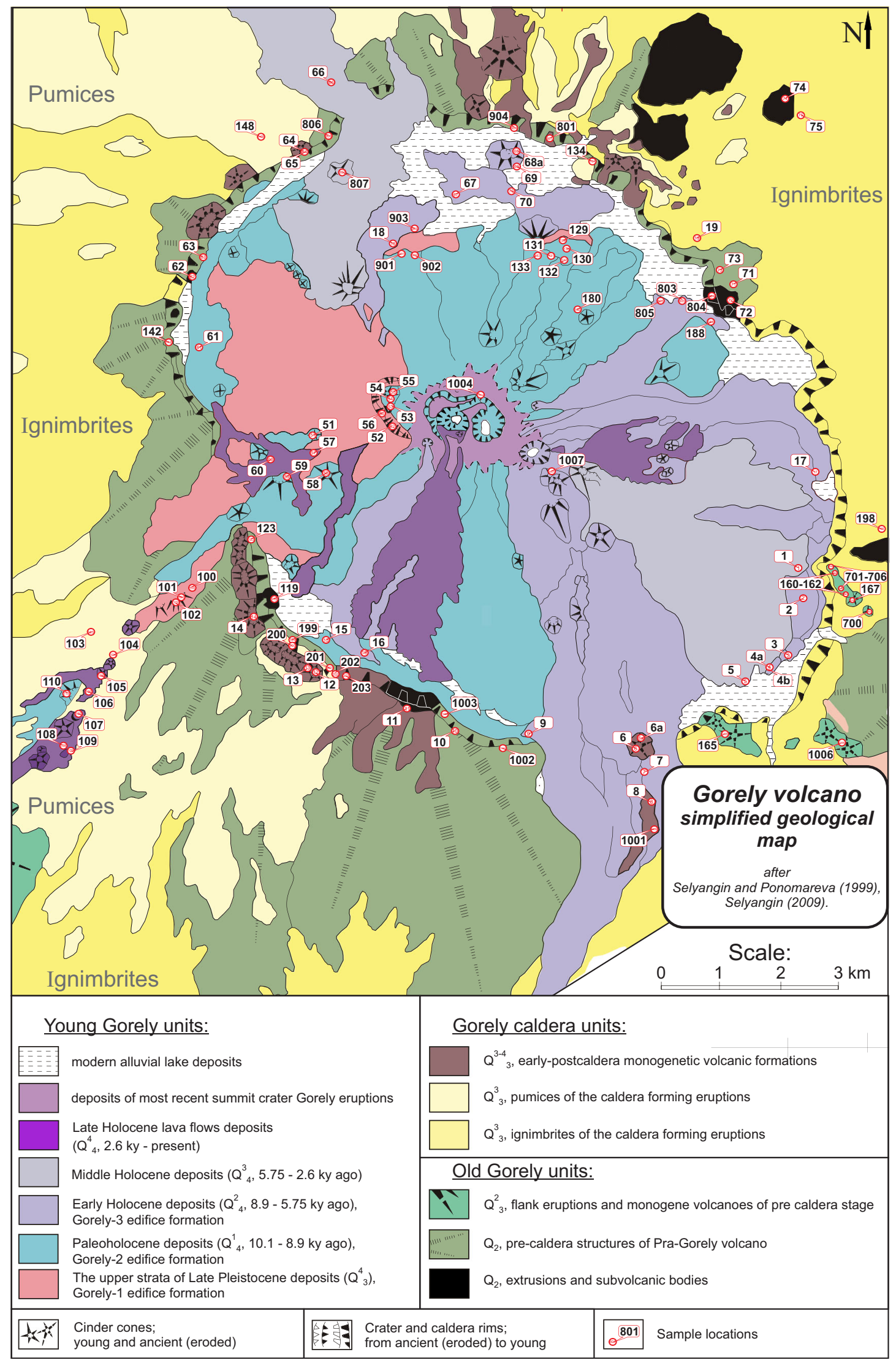

Fig. 2 Simplified geological map of Gorely volcano (after Selyangin and Ponomareva 1999; Selyangin 2009), with sample locations 
(CODES) at the University of Tasmania, Australia (Table S3). Samples were processed in a class 300 clean and analyzed using an Agilent 7700 ICP-MS with a 3rd Generation Octopole Reaction System. Samples were dissolved using high-pressure, high-temperature $\left(245{ }^{\circ} \mathrm{C}\right)$ acid digestion of whole-rock powders $(100 \mathrm{mg})$ in a PicoTrace unit using $\mathrm{HF}-\mathrm{H}_{2} \mathrm{SO}_{4}$ followed by $\mathrm{HClO}_{4}$ and final dissolution in $2 \%$ $\mathrm{HNO}_{3}-1 \% \mathrm{HCl}$. This procedure dissolves all resistant (accessory) minerals such as zircon. Element abundances were measured using international reference materials (TasBAS, TasGRAN, AGV-1, BHVO-1, FER-2) as secondary standards. Details of the analytical procedure are described by Yu et al. (2001).

\section{Calculations for plotting and modeling purposes}

Major element concentrations were normalized to $100 \%$ on a volatile-free basis with all iron expressed as $\mathrm{FeO}_{\text {total }}$. For trace element concentrations, we used XRF data for $\mathrm{Ba}, \mathrm{Cu}, \mathrm{V}, \mathrm{Cr}$, $\mathrm{Ni}, \mathrm{Zn}, \mathrm{Sr}, \mathrm{Zr}$, and $\mathrm{Rb}$ and LA-ICP-MS or solution ICP-MS data for all other elements. $\mathrm{Mg} \#=\mathrm{Mg} /\left(\mathrm{Mg}+\mathrm{Fe}^{*}\right)$, molar, where $\mathrm{Fe}^{*}$ is total $\mathrm{Fe}$ expressed as $\mathrm{Fe}^{2+} . \mathrm{Eu} / \mathrm{Eu}^{*}=\left(\mathrm{Eu}_{\mathrm{Nch}}\right) /$ $\left(\mathrm{Sm}_{\mathrm{Nch}} * \mathrm{Gd}_{\mathrm{Nch}}\right)^{1 / 2}, \mathrm{Hf} / \mathrm{Hf} *=\left(\mathrm{Hf}_{\mathrm{Nch}}\right) /\left(\mathrm{Nd}_{\mathrm{Nch}}{ }^{1 / 4} * \mathrm{Sm}_{\mathrm{Nch}}{ }^{3 / 4}\right)$, $\mathrm{Nch}$ - normalized to chondrite. For the primitive mantle normalized multi-element diagram and for Eu and $\mathrm{Hf}$ anomaly plots, we used only solution ICP-MS data. For petrological modeling, we used Petrolog3 software (ver.3.1.1.3) (Danyushevsky and Plechov 2011) and Excel spreadsheets from Lee at al. $(2009,2014)$.

\section{Electron microprobe analyses}

\section{Routine analyses}

We made electron microprobe analyses of phenocrysts and groundmass pyroxene (in five samples) and olivine (in six samples). For most analyses, we used analytical conditions of $20 \mathrm{kV}$ and $20 \mathrm{nA}$ with a $1-\mu \mathrm{m}$ beam on a Cameca SX-50 instrument at the Vernadsky Institute of Geochemistry and Analytical Chemistry (Russia) and at the University of Alaska Fairbanks (USA) and on JEOL JXA-8200 instrument at Rutgers University (USA).

\section{High-precision analyses}

We made high-precision analyses of olivine phenocrysts in five samples using a modified method of Sobolev et al. (2007) as reported by Vidito et al. (2013). We determined concentrations of major $(\mathrm{Si}, \mathrm{Mg}, \mathrm{Fe})$ and trace $(\mathrm{Mn}, \mathrm{Ni}, \mathrm{Ca})$ elements. We also analyzed $\mathrm{Al}$ in two samples including profiles across four olivine grains using a current of $300 \mathrm{nA}$ and an accelerating voltage of $20 \mathrm{kV}$. Detection limits of $\mathrm{Al}$ at a $3 \sigma$ $(99.7 \%)$ confidence level and errors $(2 \sigma)$ were obtained from the Probe for Windows program (Donovan 2012). Furthermore, $2 \sigma$ error for all elements was calculated from the San Carlos olivine standard, which was analyzed at regular intervals (every 10 analyses) throughout every run to correct for drift. The San Carlos olivine standard is only used for drift correction, not for calibration or normalization. Count times, detection limits, and analytical errors $(2 \sigma)$ are presented in Table S8. Analyses with oxide totals $> \pm 1 \%$ deviation from $100 \%$ were excluded. Structural formulas were calculated for all analyses. Analyses with deviations in stoichiometry $> \pm 1 \%$ were excluded.

\section{Olivine-spinel pairs}

To estimate magma temperatures, we used the $\mathrm{K}_{\mathrm{d}}$ of $\mathrm{Al}_{2} \mathrm{O}_{3}$ in coexisting olivines and spinels (Wan et al. 2008). Since $\mathrm{Al}_{2} \mathrm{O}_{3}$ is a trace element in olivines (around 100-200 ppm for our samples), we used the analytical procedure described above. The $\mathrm{Al}_{2} \mathrm{O}_{3}$ concentrations were corrected for background curvature in the $\mathrm{Al}$ peak region (Batanova et al. 2015). The reported $\mathrm{Al}_{2} \mathrm{O}_{3}$ contents of olivine are the average of four analyses that were separated by $6 \mu \mathrm{m}$. This effectively halves the standard error of the aluminum analyses.

Spinel inclusions were analyzed using routine microprobe methods. Olivine host compositions, coexisting spinel inclusions, and calculated temperatures (Wan et al. 2008) for two Gorely basalts ( 9 points for OG-66 and 9 points for OG-160) are presented in Table S7. Olivine data represent the average of four equidistant analyses made around (not closer than 1 diameter of spinel inclusion) individual spinel inclusions (Mironov et al. 2015). The average temperature error (one standard deviation of temperatures from four estimates) was $5{ }^{\circ} \mathrm{C}$ (within range from 1 to $1{ }^{\circ} \mathrm{C}$ ).

\section{Results}

\section{Petrographic description}

Old Gorely mafic rocks (samples OG-160-162 and OG-700706) are olivine basalts with varying abundances of unzoned olivine phenocrysts (Fig. S1.1). Plagioclase and pyroxene phenocrysts are minor constituents. All phenocrysts are equidimensional and occur in a pilotaxitic groundmass. Olivine phenocrysts contain numerous spinel inclusions. Old Gorely has several aphyric/subaphyric basalts (e.g., OG-165, Fig. S1.3) with no phenocryst phases. Intermediate rocks (basaltic andesites, Fig. S1.4; andesites, Fig. S1.5) have abundant plagioclase phenocrysts and an assemblage of Plag $+\mathrm{Cpx}+$ $\mathrm{Opx}+\mathrm{Ol}+\mathrm{Mt} \pm \mathrm{Ap}$. Old Gorely dacites (Fig. S1.6) have rare amphibole phenocrysts (Chashchin and Martynov 2011). Rhyolites are rare at Old Gorely and consist of brown obsidian glass (sample OG-13). 
Young Gorely volcanic rocks have a similar phenocryst assemblage to Old Gorely rocks, but with a greater prevalence of zoned olivine and plagioclase. Basaltic andesites (e.g., OG-4b, OG-9, OG-66; Fig. S1.9) contain plagioclase, pyroxene, and olivine phenocrysts, and the groundmass has a pilotaxitic or microlitic texture. Andesites (e.g., OG-57; Fig. S1.11) are vesicular predominantly plagioclase-bearing rocks with subordinate amounts of clinopyroxene, orthopyroxene, and olivine phenocrysts in a vitreous groundmass.

\section{Whole-rock data}

Major element analyses of 86 Gorely rocks (Table S1) show a continuum in composition from 49 to $72 \mathrm{wt} \% \mathrm{SiO}_{2}, 11$ to $0.4 \mathrm{wt} \% \mathrm{MgO}$, and 0.8 to $4.2 \mathrm{wt} \% \mathrm{~K}_{2} \mathrm{O}$. They are classified as medium to high-K basalt, basaltic andesite, andesite, dacite, and rhyolite, and show a calc-alkaline differentiation trend typical for island arc rocks (Fig. 3). The "Tholeiitic Index" (THI) (Zimmer et al. 2010), is about 0.93, corresponding to calc-alkaline series rocks $(\mathrm{THI}<1)$.

Trace element analyses are listed in Tables S1, S2, and S3. Incompatible trace elements in Gorely rocks show a strong positive correlation with indexes of differentiation (e.g., Th, Li). Concentrations of all highly incompatible trace elements continuously increase by $\sim 2$ for $\mathrm{Be}, \mathrm{Y}, \mathrm{Cd}$, and $\mathrm{Sn}, \sim 3$ for $\mathrm{Li}$, $\mathrm{Nb}, \mathrm{Ba}, \mathrm{La}, \mathrm{Ce}$, and $\mathrm{W}, \sim 4$ for $\mathrm{Zr}$ and $\mathrm{Hf}, \sim 5$ for $\mathrm{Ta}$ and $\mathrm{Pb}, \sim 6$ for $\mathrm{Rb}$ and $\mathrm{Th}$, and $\sim 7$ for Mo, Cs, and $\mathrm{U}$ during magma evolution. Gorely rocks have relatively high total REE contents and LREE-enriched patterns $\left((\mathrm{La} / \mathrm{Yb})_{n}=2.7\right.$ to 4.6).

A spider diagram (Fig. 3e) of analyzed Gorely rocks has typical island arc characteristics. They are enriched in $\mathrm{Th}, \mathrm{U}$, and $\mathrm{Pb}$, and large ion lithophile elements $\mathrm{Cs}$, $\mathrm{Rb}, \mathrm{Ba}, \mathrm{Sr}$, and $\mathrm{K}$, and depleted in high field strength elements $\mathrm{Nb}$ and $\mathrm{Ta}$ relative to REE.

In general, the Old and Young Gorely rock compositions are similar, but there are some differences (Figs. 3, 4, and 5). Old Gorely rocks have a wide compositional range, from high-Mg basalt to rhyolite, whereas Young Gorely rocks only range from basaltic andesite to dacite.

Old Gorely rocks geochemical variations are consistent with typical fractional crystallization trends (Figs. 4 and 5). At $\sim 5 \mathrm{wt} \% \mathrm{MgO}, \mathrm{CaO}$ contents drop sharply owing to the onset of clinopyroxene crystallization. Compatible trace elements $(\mathrm{Sc}, \mathrm{Ni}$, and $\mathrm{Cr}$ ) also display systematic variations with respect to $\mathrm{MgO}$. Sc, Ni, and $\mathrm{Cr}$ vary with $\mathrm{CaO}$, which is mostly controlled by clinopyroxene fractionation (Fig. 4). A weak Sc increase in basalt and its stronger decrease in more evolved lavas can be attributed to the onset of $\mathrm{Cpx}$ fractionation. $\mathrm{Ni}$ and $\mathrm{Cr}$ behavior is controlled by $\mathrm{Ol}$ and $\mathrm{Cr}$-spinel (Gorely spinels have $\sim 30 \mathrm{wt} \%$ of $\mathrm{Cr}_{2} \mathrm{O}_{3}$, see Table S7) crystallization, respectively (Kinzler et al. 1990; Righter et al. 2006). Olivines are responsible for $\mathrm{Ni}$ variations in magmas, and Old Gorely olivines have inclusions of $\mathrm{Cr}$-spinel that are responsible for $\mathrm{Cr}$ variations in magma. Therefore, in Gorely mafic rocks, $\mathrm{Ni}$ and $\mathrm{Cr}$ behave similarly (Fig. 4). The strong $\mathrm{Ni}$ and $\mathrm{Cr}$ depletion is explained by only $\mathrm{Ol}$ and $\mathrm{Sp}$ fractionation. However, when Cpx and Plag start to fractionate in significant amounts (at $\sim 5 \mathrm{wt} \%$ of $\mathrm{MgO}$ ), $\mathrm{Ni}$ and $\mathrm{Cr}$ depletion slows down dramatically in Old Gorely magmas (Fig. 4). The Cpx onset at $\sim 5 \mathrm{wt} \%$ of $\mathrm{MgO}$ is in good correlation with mineralogical data. According to our microprobe measurements, the highest $\mathrm{Mg} \#$ of Old Gorely Cpx is 78 (Table S4), which should be in equilibrium with magma with $5 \mathrm{wt} \%$ of $\mathrm{MgO}$ (modeled with the help of Petrolog3 software, using model of Danyushevsky 2001).

Plagioclase is not a prevalent phenocryst in Old Gorely basaltic lavas and there are no Eu anomalies in basalts (Fig. 4). However, the intermediate and acidic rocks have numerous plagioclase phenocrysts, and these rocks have a strong negative $\mathrm{Eu}$ anomaly (Eu/Eu* constantly decreases from $\sim 0.96$ to $\sim 0.59$ in range of $\mathrm{MgO}$ from $\sim 5$ to $0.8 \mathrm{wt} \%$ ), indicating plagioclase fractionation as suggested by $\mathrm{Al}_{2} \mathrm{O}_{3}$ and $\mathrm{Sr}$ (Fig. 4). According to Duggen et al. (2007), Hf anomalies (Hf/ $\mathrm{Hf}^{*}$ ) reflect the joint fractionation of Plag and Cpx. Thus, Hf anomaly variations in Old Gorely rocks confirm that Plag and Cpx start to fractionate at $\sim 5 \mathrm{wt} \%$ of $\mathrm{MgO}$ (Fig. 4).

There is another sharp break at around $~ 3.5 \mathrm{wt} \% \mathrm{MgO}$ where $\mathrm{FeO}$ and $\mathrm{TiO}_{2}$ start to decrease, owing to the onset of magnetite fractionation (Fig. 5). $\mathrm{V}$ abundances show a slight increase in basalts, followed by depletion in more evolved compositions, indicating the onset of magnetite crystallization. $\mathrm{P}_{2} \mathrm{O}_{5}$ drops at $\sim 2.5 \mathrm{wt} \%$ of $\mathrm{MgO}$, owing probably to apatite crystallization. $\mathrm{Zr}$ behaves as an incompatible element, and we infer no role for zircon crystallization. It is consistent with the previous studies. Seligman et al. (2014) searched for zircons in the most silicic eruptive products (where one would expect to find zircons) and could not find them. Only one zircon was found, and it was determined to be a xenocryst upon U$\mathrm{Pb}$ dating (Seligman et al. 2014). The major and compatible trace element variations (Figs. 4 and 5) can be interpreted with the following sequence of mineral crystallization: $\mathrm{Ol}+\mathrm{Sp} \rightarrow \mathrm{Pl}+\mathrm{Cpx}+\mathrm{Ol} \rightarrow \mathrm{Pl}+\mathrm{Cpx}+\mathrm{Mt}+\mathrm{Ol} \rightarrow$ $\mathrm{Pl}+\mathrm{Cpx}+\mathrm{Mt}+\mathrm{Ap} \pm \mathrm{Ol}$ and will be verified by modeling in the "Discussion" section.

Although fractional crystallization explains the majority of Old Gorely data, the sample OG-72 with about $5.5 \mathrm{wt} \%$ $\mathrm{MgO}$ has higher concentrations of $\mathrm{Cr}$ and $\mathrm{Ni}$ and lower concentrations $\mathrm{Sr}, \mathrm{V}$, and $\mathrm{P}_{2} \mathrm{O}_{5}$ than expected for fractional crystallization (Figs. 4 and 5). These concentrations are compatible with magma mixing, so we consider the 
Fig. 3 Gorely sample classifications: a total alkali versus silica (TAS) diagram (Le Bas et al. 1986); b $\mathrm{K}_{2} \mathrm{O}$ versus $\mathrm{SiO}_{2}$, showing that Gorely rocks belong to the medium-K and high-K types (Le Maitre et al. 1989); c $\mathrm{SiO}_{2}$ versus $\mathrm{FeO} / \mathrm{MgO}$ ratio with subdivision lines which are after Miyashiro (1974) and Arculus (2003), THoleiitic Index (THI) was calculated using the method of Zimmer et al. (2010). d $\mathrm{SiO}_{2}$ versus $\mathrm{Mg} \#$ illustrates the ranges of $\mathrm{SiO}_{2}$ and $\mathrm{Mg} \#$ for Gorely volcano rocks. e Trace element patterns on selected Gorely samples (ICP-MS analysis only), samples normalized using values from Sun and McDonough (1989). Light gray bar at (a), (b), (c), and (d) demonstrates the range of compositions of calderaforming eruptions (ignimbrites and pumices) a

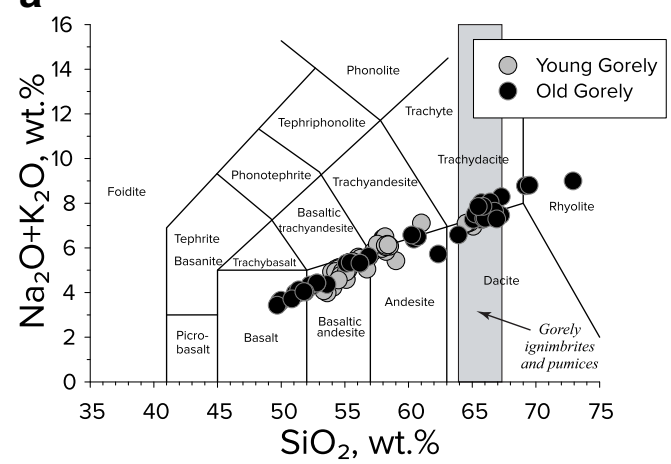

C

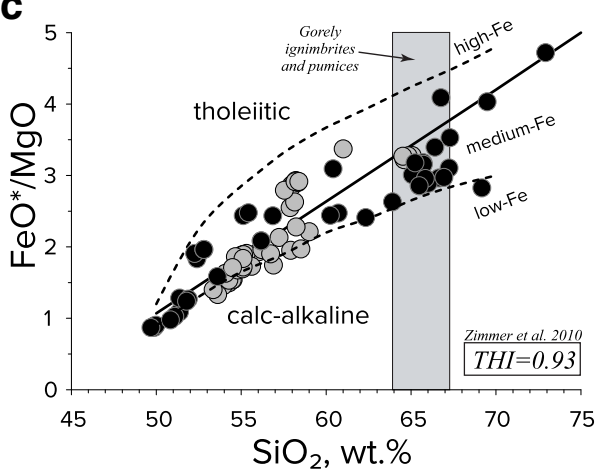

e

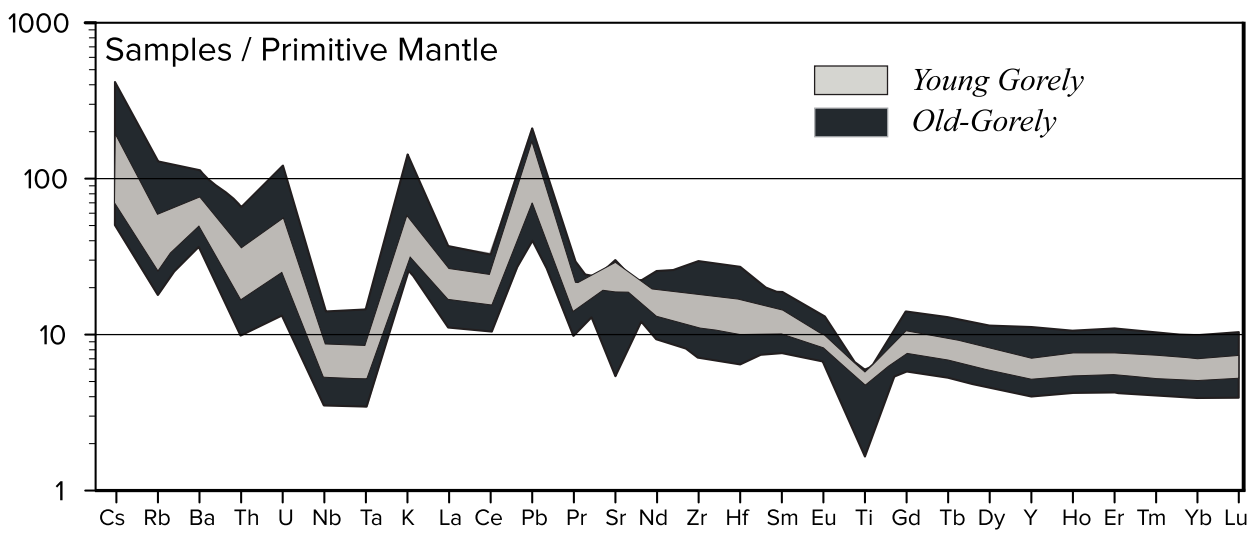

b
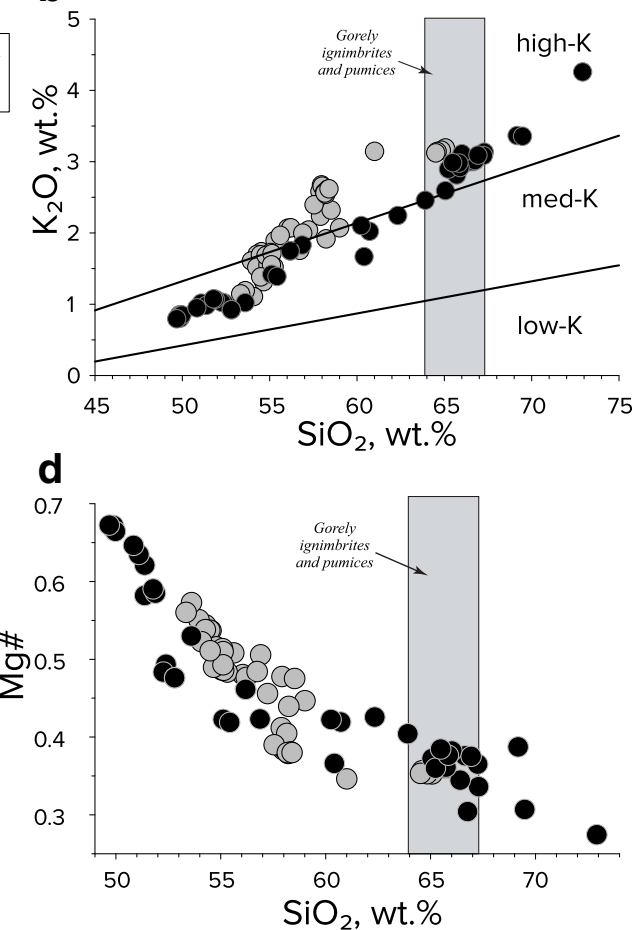


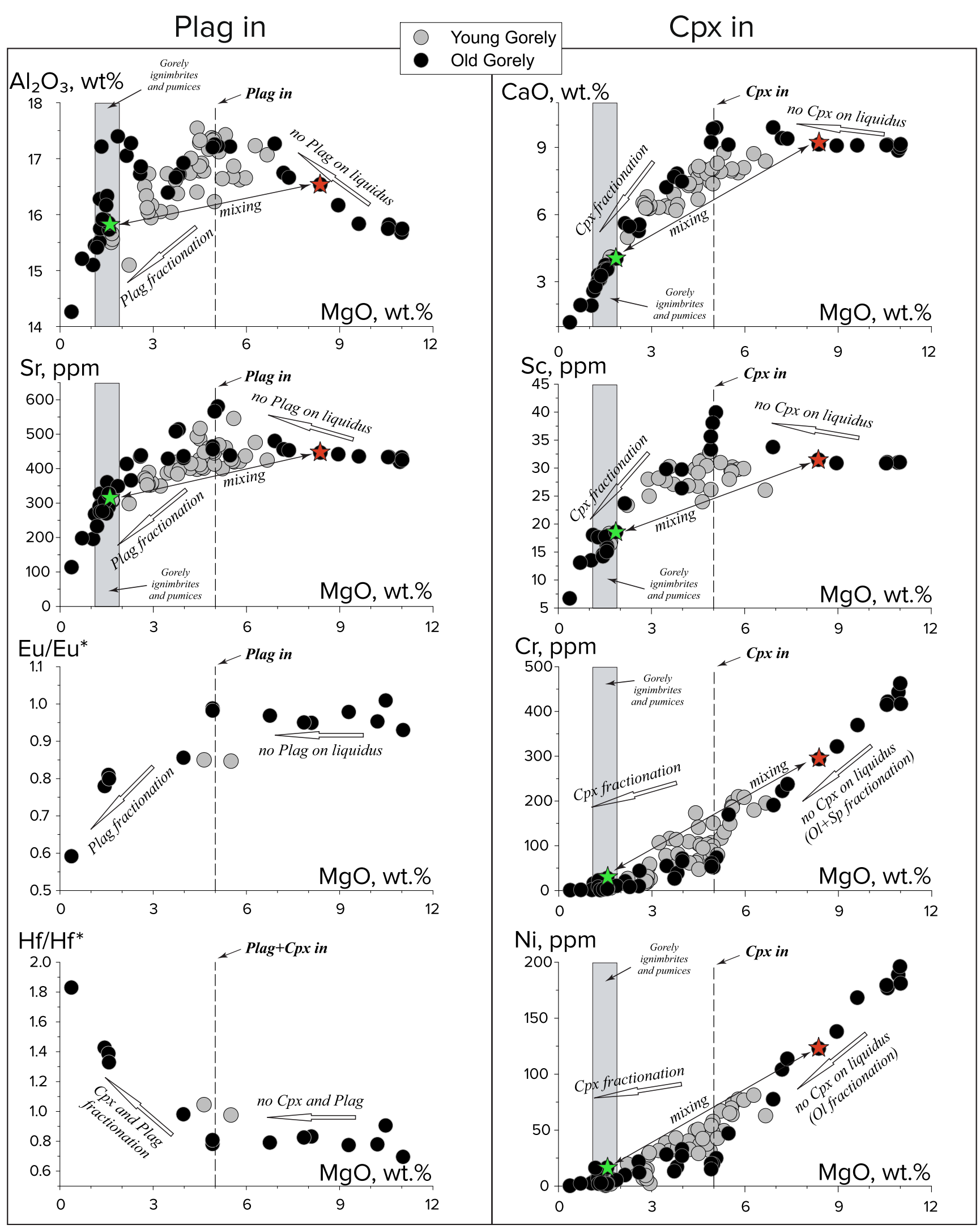

compositions vary more significantly $\left(\mathrm{En}_{39-46}, \mathrm{Wo}_{33-43}\right)$. The least calcic clinopyroxenes are microlites (Fig. 6).
The pyroxene $\mathrm{Mg}$ \# range for Old Gorely (64-78) is similar to Young Gorely (62-77) rocks (Fig. 6b, d). Orthopyroxene occurs 


\section{Accessory minerals fractionation}
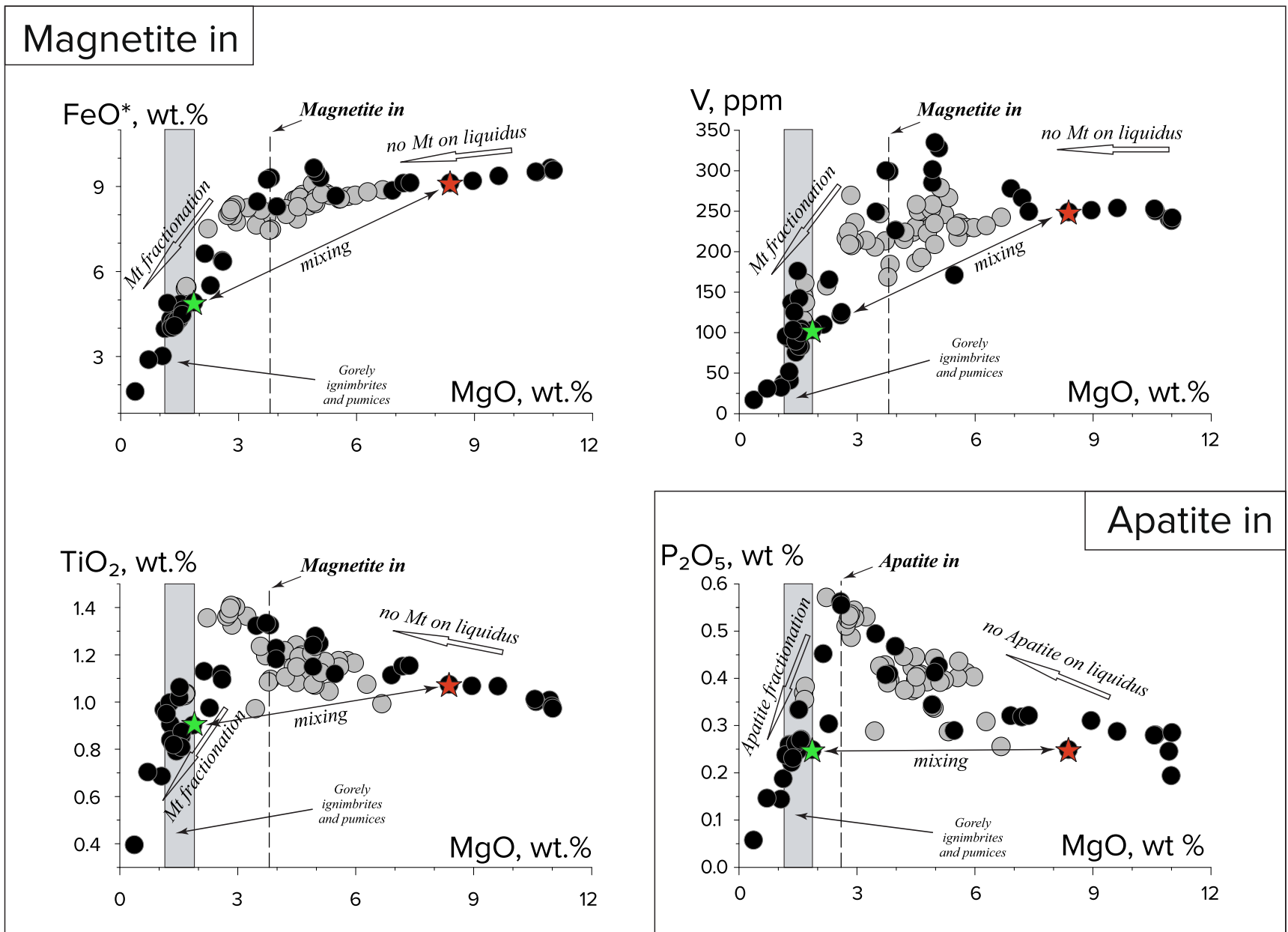

Fig. 5 Interpretation of expected fractional crystallization processes for Old Gorely volcanics (black circles): appearance of accessory minerals. The onset of magnetite crystallization at $\mathrm{MgO}$ is $\sim 3.8 \mathrm{wt} \%\left(\mathrm{SiO}_{2}\right.$ $\sim 55 \mathrm{wt} \%$ ) illustrated by $\mathrm{FeO}, \mathrm{TiO}_{2}$, and $\mathrm{V}$ versus $\mathrm{MgO}$ diagrams, and

the onset of apatite crystallization at $\mathrm{MgO}$ is $\sim 2.7 \mathrm{wt} \%\left(\mathrm{SiO}_{2} \sim 60 \mathrm{wt} \%\right)$ illustrated by $\mathrm{P}_{2} \mathrm{O}_{5}$ versus $\mathrm{MgO}$ diagram. Light gray bar at the plots demonstrates the range of compositions of caldera-forming eruptions (ignimbrites and pumices)

less often than clinopyroxene and has a narrower Mg\# range. In general, pyroxene compositions from this work are consistent with the ones from previous studies (Chashchin and Martynov 2011; Tolstykh et al. 2012; Seligman et al. 2014) (Fig. 6a).

\section{Olivine compositions}

Olivine phenocrysts vary over the range of $\mathrm{Fo}_{88-68}$ (Fig. 7; Tables S5-S8). The most magnesian varieties ( $\left.\mathrm{Fo}_{86-82}\right)$ occur in high-Mg olivine basalts and in the cores of olivine phenocrysts from intermediate rocks (basaltic andesites and andesites). The rims of phenocrysts and microlites in the basalts, basaltic andesites, and andesites are $\mathrm{Fo}_{70-60}$.

The most frequent olivine compositions are $\mathrm{Fo}_{83-85}$ for both Old and Young Gorely rocks (Fig. 7). However, Old Gorely olivine compositions are in equilibrium with their host lava whole-rock compositions

(Fig. 7a), while Young Gorely rocks contain nonequilibrium olivines (Fig. $7 b, c)$. The nonequilibrium olivines were found in such Young Gorely rocks as basaltic andesite (up to $\mathrm{Fo}_{88}$ in sample OG-66) and even andesite (up to $\mathrm{Fo}_{83.5}$ in sample OG-57). Nonequilibrium minerals are typical for magmas generated by magma mixing, but it also might be explained as a result of fractional crystallization where previously crystallized phases have not been physically separated or reacted out of the magma.

\section{Plagioclase compositions}

We did not analyze plagioclase compositions, except for acquiring back-scattered electron images. However, according previous works (Chashchin and Martynov 2011; Tolstykh et al. 2012; Seligman et al. 2014), plagioclase from Gorely rocks spans a continuum in composition from $\mathrm{An}_{87}$ (mafic rocks) to $\mathrm{An}_{35}$ (silicic rocks) with the most common compositions $\sim \mathrm{An}_{40-55}$. 
Fig. 6 Pyroxene compositions from Gorely volcano rocks. a Systematics (after Morimoto et al. 1988) of pyroxene phenocrysts and microlite analyses in Gorely lavas (this work) compared to previously published data (from Chashchin and Martynov 2011; Seligman et al. 2014). Frequency distribution of pyroxene $\mathrm{Mg} \# \mathbf{b}$ in Old Gorely rocks; c Px phenocryst zoning (Mg\# core $-\mathrm{Mg} \#$ rim) frequency distribution in Young Gorely rocks; $\mathbf{d}$ in Young Gorely rocks
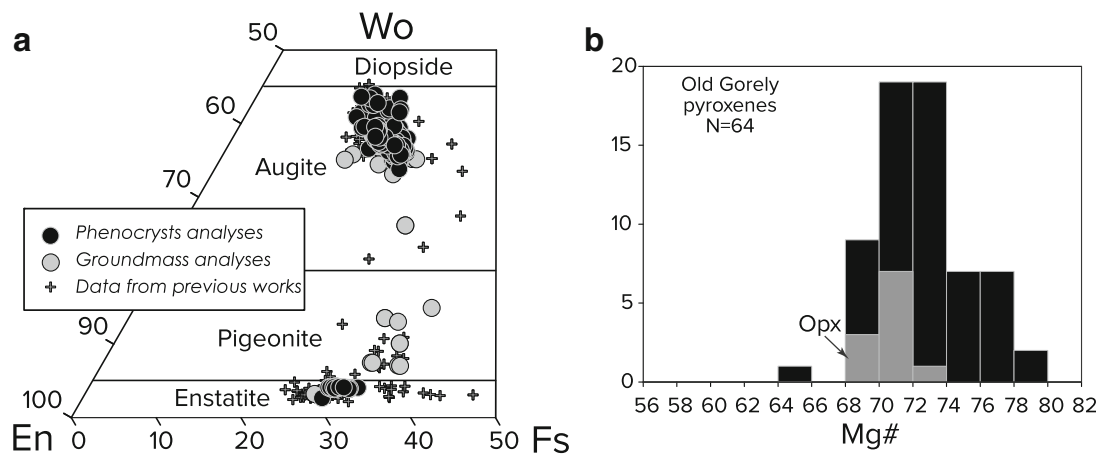

C

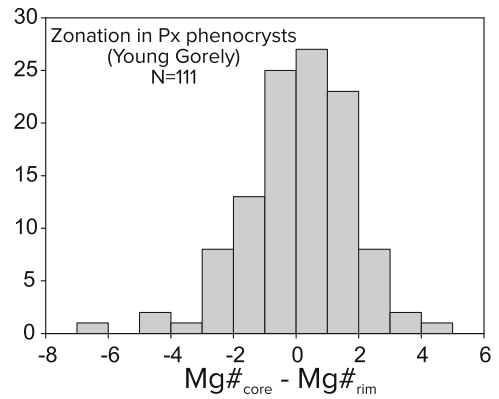

d

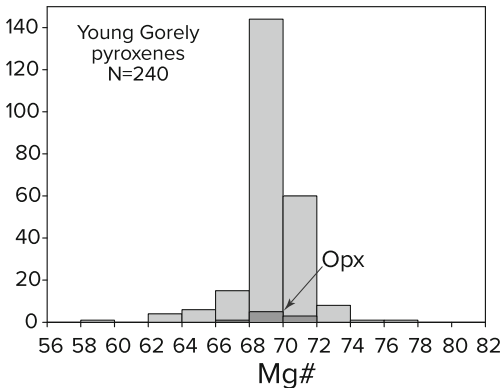

\section{Discussion}

Both Old and Young Gorely volcano series are genetically related (Fig. 3). However, the series of voluminous $\left(\sim 100 \mathrm{~km}^{3}\right)$ caldera-forming eruptions (Seligman et al. 2014) separating them had the potential to significantly transform Gorely's magma-feeding system. Magma chamber depletion, combined with roof collapse, could affect some features of the chemical trends of post-caldera volcanic rocks. Here we present whole-rock and mineral chemistry data along with petrological modeling that support a major role of magma mixing in the genesis of the post-caldera rocks of Young Gorely. In contrast, the Old Gorely lavas, produced in their early shield building stage, are well explained by fractional crystallization and crustal melting.

\section{Phenocryst zoning}

A hybrid genesis of rocks is usually identified based on the occurrence of melanocratic nodules, unequilibrated mineral associations, corroded phenocrysts, and significant variations in the zoning of phenocrysts (e.g., Anderson 1976; Sakuyama 1979; Eichelberger 1978, Eichelberger 1980). The phenocrysts from Young Gorely rocks demonstrate some of these compositional features.

\section{Zonation in pyroxene grains}

The comparison of composition in the cores and rims of phenocrysts allows zonation to be determined (see Table S4). In
Young Gorely rock sample OG-66, there is no significant zonation in pyroxene (Fig. 6c). The average difference between $\mathrm{Mg} \#_{\text {core }}$ and $\mathrm{Mg} \#_{\text {rim }}$ in 111 grains is $0.1 \pm 1.9$ (standard deviation). This variation ( $\pm 1.9 \mathrm{Mg} \#$ units) might reflect the analytical error. There are insignificant amounts of normally zoned grains $\left(\mathrm{Mg} \#_{\text {core }}-\mathrm{Mg} \#_{\text {rim }}=\right.$ up to 7.8$)$ and reverse zoned grains $\left(\mathrm{Mg} \#_{\text {core }}-\mathrm{Mg} \#_{\text {rim }}=\right.$ up to -8.4$)$. Thus, the pyroxene data do not argue for magma mixing for Young Gorely magmas.

\section{Zonation in olivine grains}

The olivine in Old Gorely rocks are usually unzoned (Fig. 8a, b) in contrast to Young Gorely rocks (Fig. 8c, d), which contain reversely zoned phenocrysts. The 2-point core-rim measurements allow estimation of the frequency of zoned phenocrysts (see Table S5). The average difference between Fo\# $\#_{\text {core }}$ and Fo\# $\#_{\text {rim }}$ in 158 grains of Old Gorely olivines (Fig. 8a) is 1 \pm 2 (standard deviation). This variation is within analytical error. Furthermore, $\sim 18 \%$ of grains are normally zoned $\left(\right.$ Fo $\#_{\text {core }}-F o g \#_{\text {rim }}=$ up to 11.9$)$ and only $\sim 2 \%$ of grains are reversely zoned $\left(\mathrm{Fo} \#_{\text {core }}-\mathrm{Fo} \#_{\text {rim }}=\right.$ up to -3.6$)$. In contrast, Young Gorely olivines demonstrate a wider distribution of Fo\# $\#_{\text {core }}-$ Fo\# $\#_{\text {rim }}$ values (Fig. 8c). The average difference between Fo\# $\#_{\text {core }}$ and Fo\# $\#_{\text {rim }}$ in 102 grains of Young Gorely olivines is $1.3 \pm 4.5$ (standard deviation). The end members Fo\# $\#_{\text {core }}-$ Fo $\#_{\text {rim }}$ values for Young Gorely olivines are 16.0 (normal zoning) and -10 (reverse zoning).

For a better visualization of the difference in degree of olivine phenocryst zonation between Old and Young Gorely 

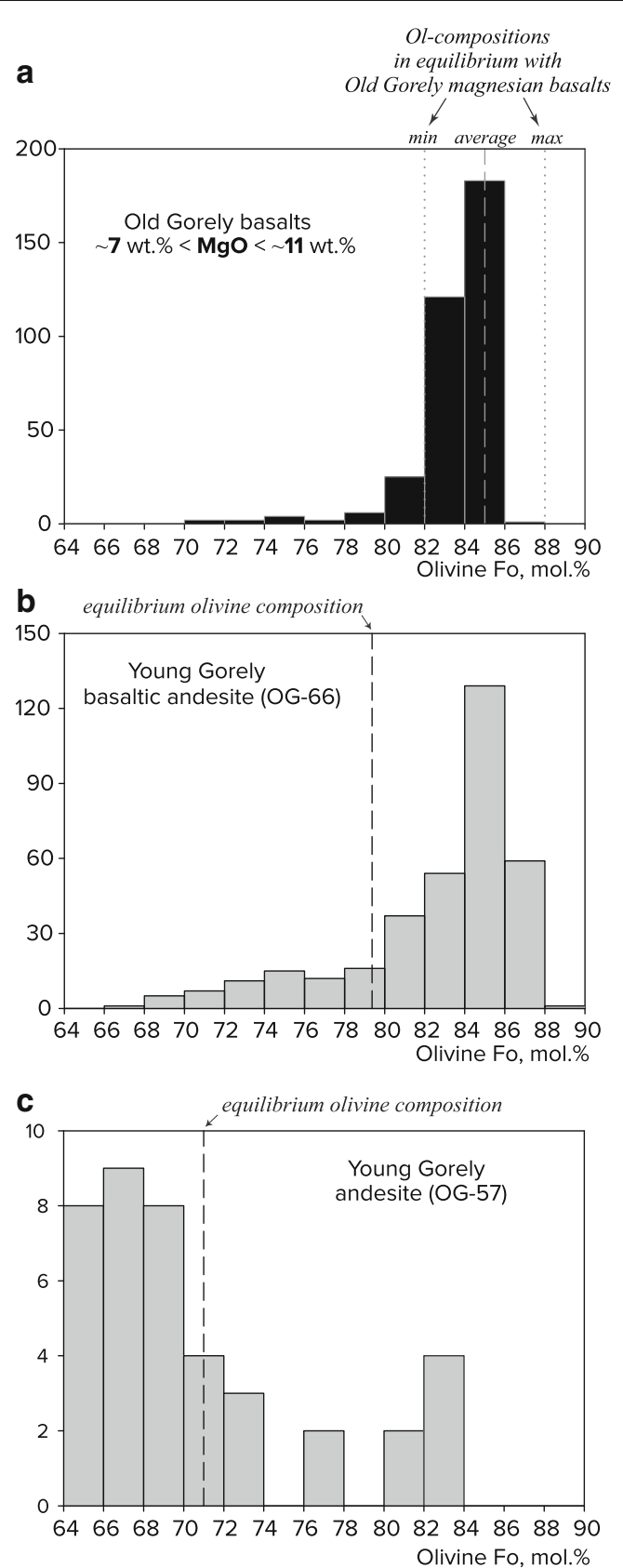

Fig. 7 Olivine compositions for rocks from Gorely volcano. Frequency distribution of olivine Fo\# a in Old Gorely basalts (samples OG-700 OG-704), b in a Young Gorely basaltic andesite (sample OG-66), and $\mathbf{c}$ in a Young Gorely andesite (sample OG-57). Dashed line shows the modeled (after Ford et al. 1983) olivine composition that is in equilibrium with the sample whole-rock composition

olivines, we measured 5-point core-rim profiles in two samples (Table S6): 60 profiles for OG-161 (Old Gorely) and 28 profiles for OG-1004 (Young Gorely). This number of profiles is enough for statistically estimating the behavior of olivine core-rim chemistry (Fo\#) changes between Old and Young Gorely. Since Fo\# varies in different grains significantly (Fo\# $_{\text {core }}$ is from 65 to 85 for OG-1004 and from 81.9 to 84.9 for OG-161, for example), we normalize every profile Fo\# value to its midpoint (point \#3 out of 5) value. Also since the grains vary widely in size for both Old $(340-750 \mu \mathrm{m})$ and Young Gorely $(140-630 \mu \mathrm{m})$, we used equal distances between measurement points for comparison of profiles shape. Old Gorely olivine grain profiles look completely unzoned except for the rims (Fig. 8b), while Young Gorely olivine profiles demonstrate a wide range of zonation (Fig. 8d). Furthermore, Young Gorely olivines are often resorbed significantly (Fig. 9a, b).

Thus, Old Gorely olivines are mostly unzoned and in equilibrium with the host lava, whereas Young Gorely olivines are statistically more zoned and usually not in equilibrium with their host lava.

\section{Zonation in plagioclase grains}

Chashchin and Martynov (2011) noted that unzoned plagioclase phenocrysts are typical for rocks of Old Gorely, while rocks of Young Gorely contain plagioclase with reverse zoning. Our back-scattered electron (BSE) images demonstrate that the Young Gorely plagioclase phenocrysts contain resorption, sieving, and zoning textures (Fig. 9c-f) that can be produced during magma mixing (e.g., Perugini and Poli 2012).

Olivine and plagioclase phenocrysts strongly support lack of mixing in Old Gorely magmas and mixing in the Young Gorely magmas. The lack of zoning in pyroxene may be due to its relatively late arrival in the crystallization history and the relative ease for re-equilibration in pyroxene compared to plagioclase.

\section{Crustal assimilation, fractional crystallization, and magma mixing}

\section{Crustal assimilation}

Potential crustal contributions to Gorely magmas were examined in previous works. Duggen et al. (2007), based on $\mathrm{Pb}$ isotope compositions of Gorely rocks, suggested that slight assimilation of crustal material cannot be excluded for the more evolved Gorely lavas. Seligman et al. (2014) used energy-constrained assimilation-fractional crystallization (EC-AFC) modeling (Bohrson and Spera 2001; Spera and Bohrson 2001) to determine the crustal contribution quantitatively. Based on $\mathrm{Sr}, \mathrm{Nd}$, and $\mathrm{O}$ isotope ratios, Seligman et al. (2014) demonstrated the possibility of ignimbrite-forming Gorely magmas assimilating rocks from the neighboring 11 Ma Akhomten granitic massif.

In order to estimate the degree of contribution to Gorely magma generation of such processes as crustal assimilation, fractional crystallization, and recharging-evacuating, we did recharge-evacuation-fractional crystallization (REFC) modeling (Lee et al. 2014) using trace element concentrations of Gorely rocks (Fig. 10). We tested between REFC, assimilation, and fractional crystallization models. The open system 

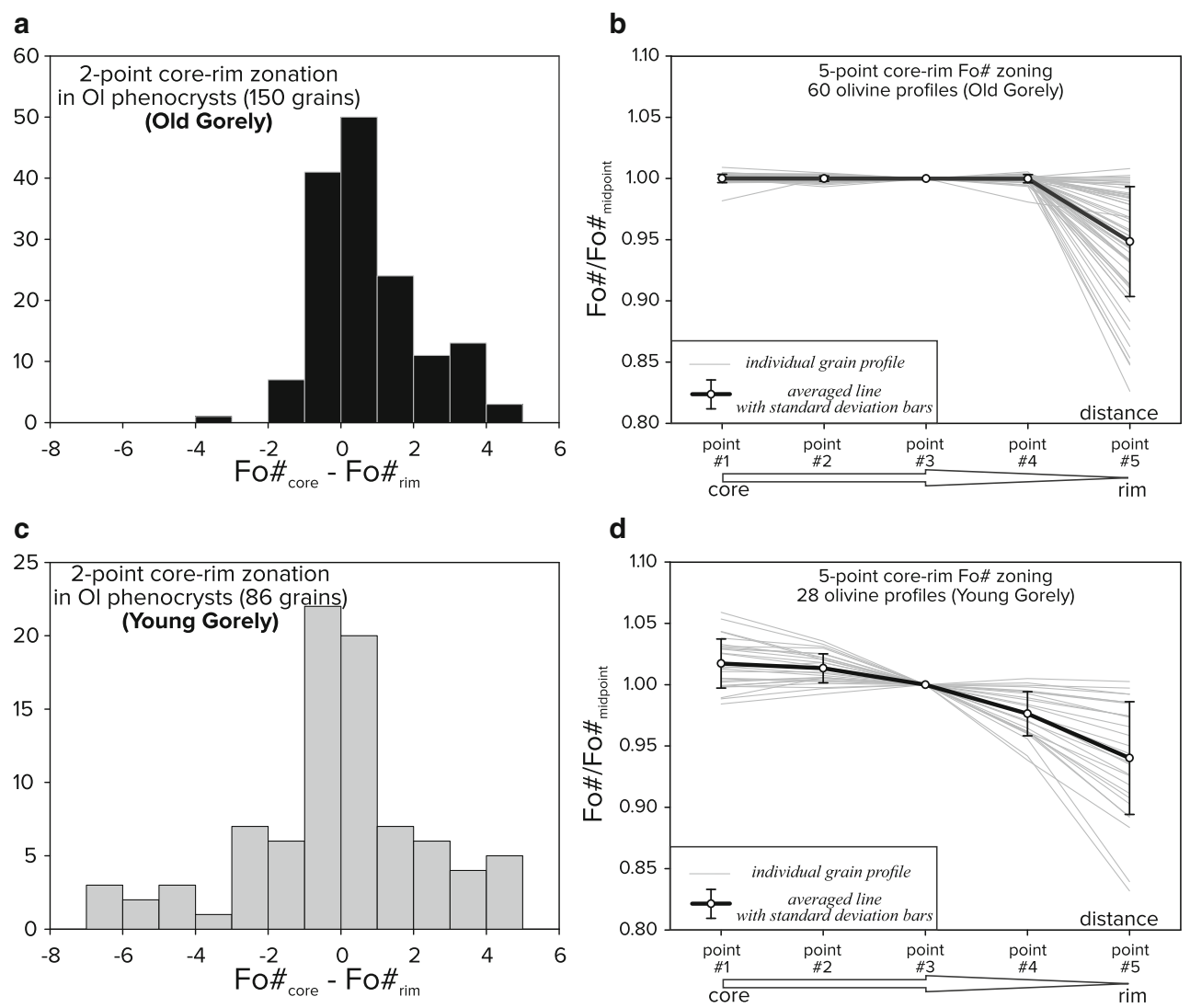

Fig. 8 Distribution of zoned and unzoned olivine grains in Old and Young Gorely rocks. a, c Frequency distribution of core-rim zonation $\left(\mathrm{Fo \#}_{\text {core }}-\mathrm{Fo} \#_{\text {rim }}\right)$ in olivine phenocrysts of Old Gorely (a) and Young Gorely (c) rocks. Positive values reflect zoned grains (Fo\# ${ }_{\text {core }}>$ Fo\# $\#_{\text {rim }}$ ); unzoned grains have $\mathrm{Fo}_{\text {core }} \approx \mathrm{Fo} \#_{\text {rim }}$; negative values reflect reverse zoning $\left(\mathrm{Fo \#}_{\text {core }}<\mathrm{Fo} \#_{\text {rim }}\right)$. The histograms are based on core-rim (2 points per grain) electron microprobe measurements (Table S5) of the

following samples: OG-66 (Young Gorely), OG-160, OG-161, OG-167, OG-701, OG-14 (Old Gorely). b, d Five-point core-rim profiles for Gorely olivines (Table S6): b 60 olivine profiles with averaged line and standard deviation bars from sample OG-161 (Old Gorely) and c 28 olivine profiles with averaged line and standard deviation bars from sample OG-1004 (Young Gorely)

fractionation process implies large contribution of REFC, which should be expressed via such effects as existence of steady-state liquid (SSL) compositions (which are similar the products of equilibrium crystallization), with dependence of the number of REFC cycles required to achieve SSL on the partition coefficient of each element (Lee et al. 2014; Portnyagin et al. 2015).

We tried to model assimilation with neighboring sub-volcanic/intrusive bodies (see sample OG-74) similar to Seligman et al. (2014). Figure 10 demonstrates the domination of fractional crystallization processes (in a closed magmatic system) for the whole range of compositions. However, crustal rock assimilation plays a significant role for the evolved magmas.

\section{Mixing versus fractional crystallization whole-rock trends}

Mixing of magmas produces straight lines on element-element plots (Langmuir et al. 1978). In contrast with Old Gorely magmas, the compositions for Young Gorely samples generally lie in the roughly triangular region between the fractional

crystallization path of Old Gorely and a linear mixing line between basalt and andesite compositions (Figs. 4 and 5). The diagrams of such elements as $\mathrm{K}_{2} \mathrm{O}$ (Fig. 3), $\mathrm{Al}_{2} \mathrm{O}_{3}$, Sr, $\mathrm{CaO}, \mathrm{Sc}, \mathrm{Cr}$, Ni (Figs. 4 and 11), and $\mathrm{V}$ and $\mathrm{FeO}$ (Fig. 5) are obvious examples of the role of mixing in the genesis of postcaldera (Young Gorely) magmas. Magma mixing most significantly affected the $\mathrm{Cr}$ and $\mathrm{Ni}$ concentrations, because they are the most contrasting in the primitive and evolved rocks. In the $\mathrm{Cr}$ versus $\mathrm{SiO}_{2}$ plot (Fig. 11a), the magma evolution path predicted for the fractional crystallization of basaltic melt has a hyperbolic shape and leads to a significant depletion of the melts in $\mathrm{Cr}$ (as well as $\mathrm{Ni}$ ) during early crystallization stages. The variations of $\mathrm{TiO}_{2}$ and $\mathrm{P}_{2} \mathrm{O}_{5}$ with $\mathrm{MgO}$ (Fig. 5) make clear that some Young Gorely magmas are consistent with fractional crystallization. The cluster of data close to $3 \mathrm{wt} \% \mathrm{MgO}$ are all from Young Gorely, and in all plots, they are consistent with fractional crystallization path defined by the Old Gorely data. Therefore, fractional crystallization is clearly important for these samples, but most Young Gorely samples occur in a cluster between the fractional 
Fig. 9 Examples of resorption and zoning textures produced during magma mixing. a, b Backscattered electron (BSE) images of resorbed olivine grains from Young Gorely sample OG-1004; c, $\mathbf{d}$ BSE images of oscillatory zoning in plagioclase crystals from Young Gorely sample OG66 ; e plagioclase crystal (sample OG-66) showing several resorption and growth zones; f a zoned plagioclase crystal with a resorbed core from sample OG-66 (Young Gorely). Variations in gray-scale in plagioclase denote compositional zoning from Anpoor (dark) to An-rich (bright) a

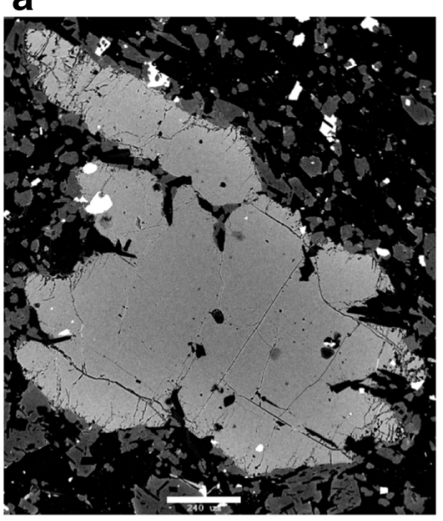

c

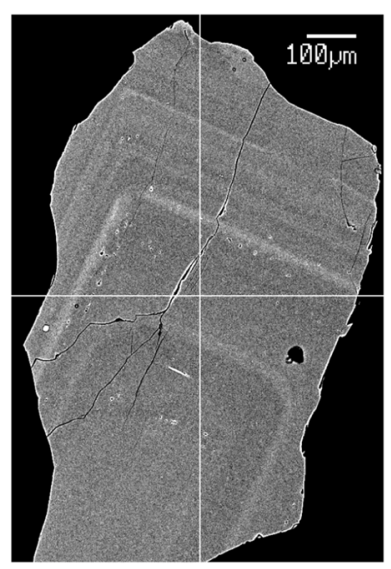

e

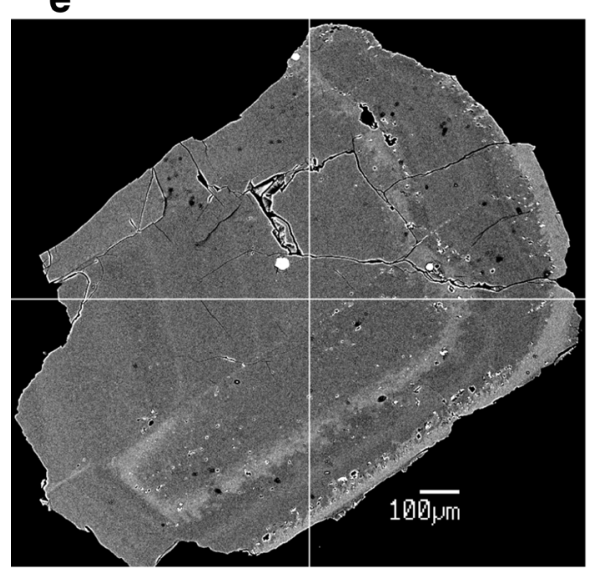

d b
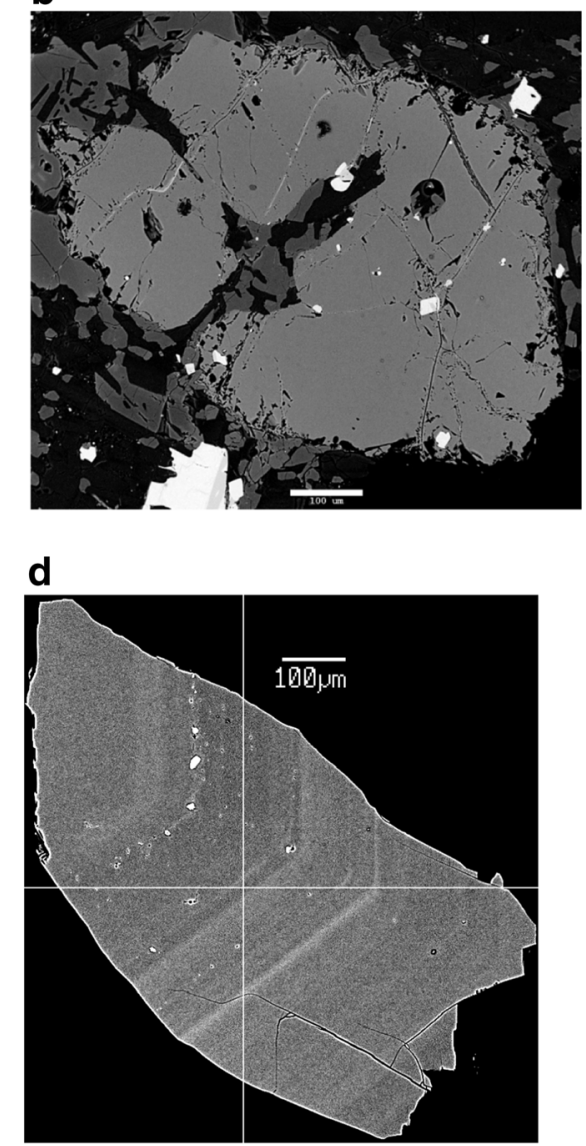

f

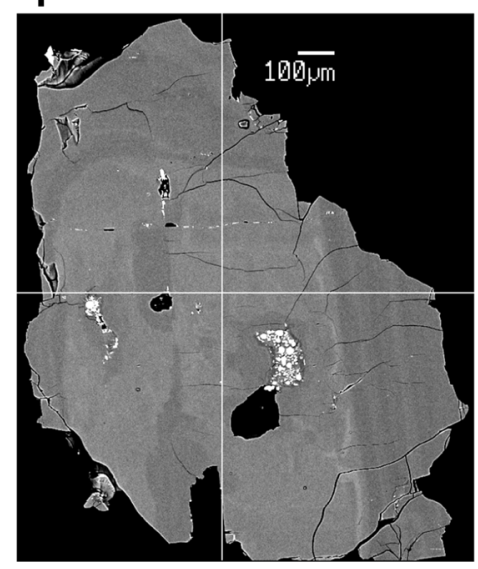

crystallization path and the mixing line between representative basalt and andesite samples, demonstrating a much more important role for magma mixing in the Young Gorely magmas.

\section{Olivine compositions}

Magma mixing also affected the composition of minerals during earlier crystallization stages. Fractional crystallization of olivine will rapidly deplete $\mathrm{Ni}$ in a basaltic melt and, consequently, in the equilibrium olivine (e.g., Ruprecht and Plank 2013). These differences are seen between Young and Old Gorely rocks (Fig. 12). If primitive and evolved melts mix, the hybrid magma bears a higher Ni concentration, at the same Fo\#, than the differentiation products of basalts. Olivine crystallizing from such a hybrid magma should also have elevated $\mathrm{Ni}$ concentrations (e.g., Straub et al. 2008). A similar affect might be seen in $\mathrm{Ca}$ in olivine concentrations (Fig. 13). 


\section{Incompatible elements}
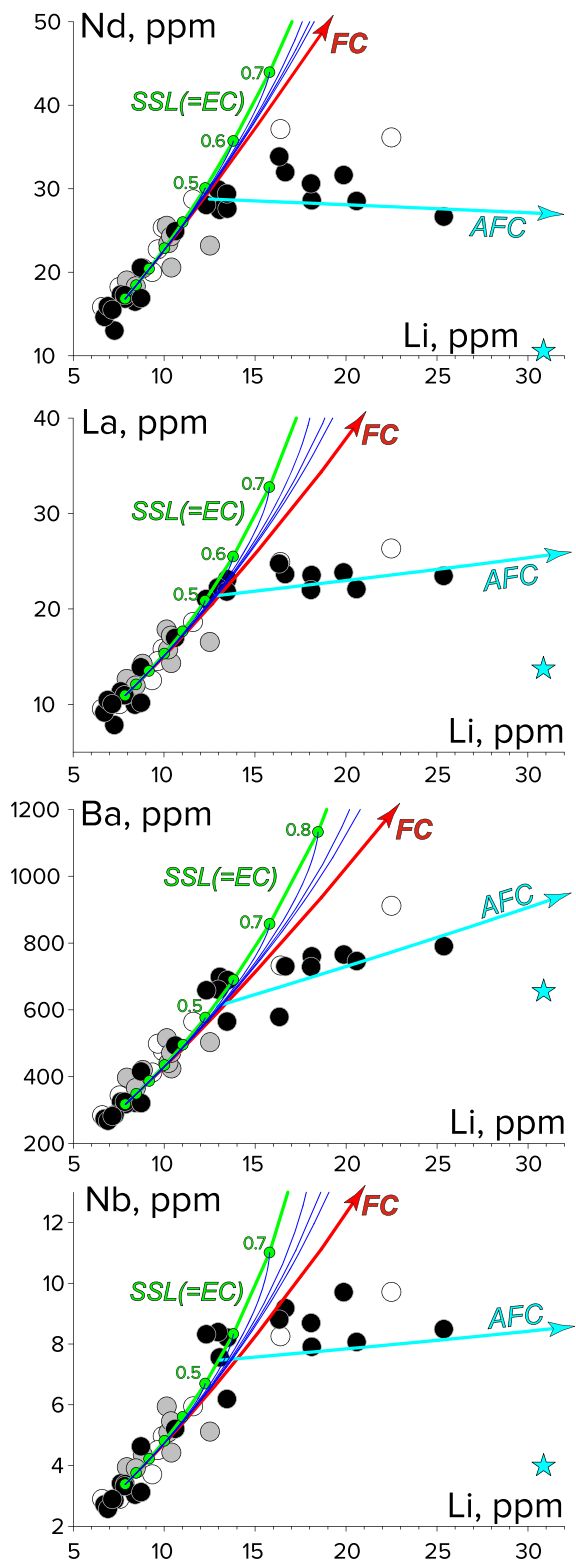

Fig. 10 Evidence for the origin of Gorely series in a closed magmatic system. Behavior of incompatible elements $(\mathrm{Nd}, \mathrm{La}, \mathrm{Ba}, \mathrm{Nb})$ and their ratios illustrates the dominant role of fractional crystallization $(F C)$ and crustal assimilation $(A F C)$ in the evolution of Gorely magmas whereas recharge-eruption fractional crystallization $(R E F C)$ do not play the major role in the origin of Gorely magma series. Thick red line shows trend for single-stage fractional crystallization $(F C)$. Thick green line shows trend of REFC steady-state liquids ( $S S L$ ). SSL correspond to the products of equilibrium crystallization $(E C)$ from the same parental melt. Numbered

\section{Incompatible elements'} RATIOS
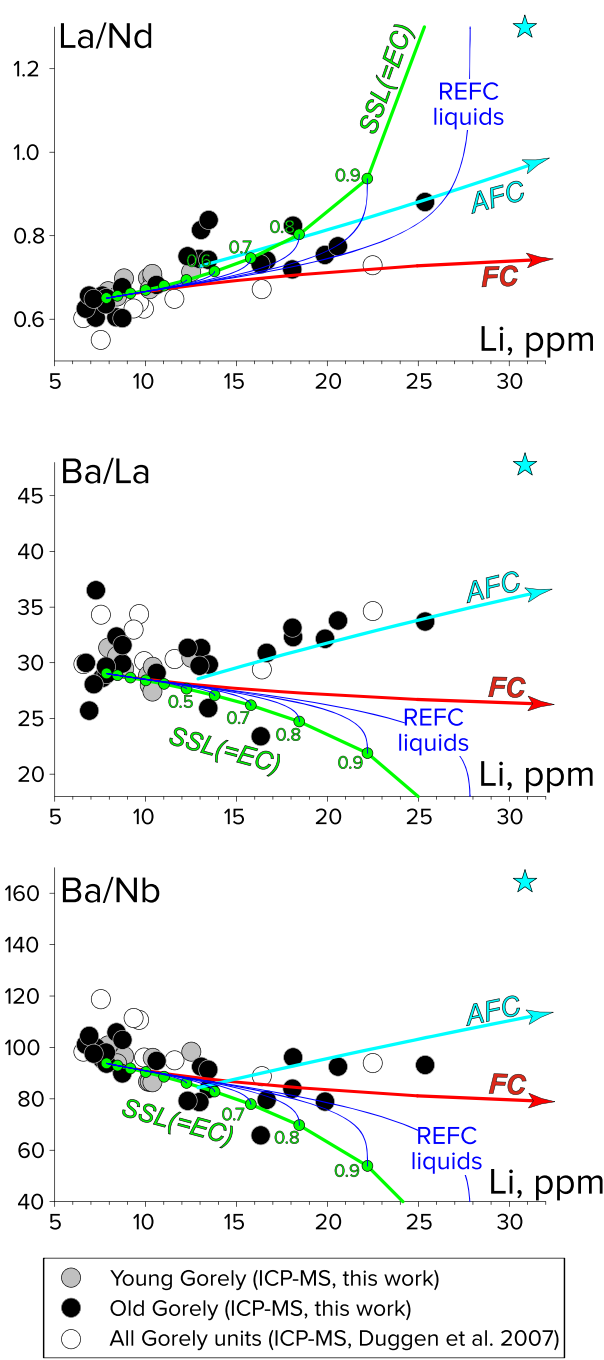

circles on the SSL trend denote different ratios of crystallized magma relative to erupted magma. The numbers also exactly correspond to degrees of equilibrium crystallization. Thin blue lines denote trends for intermediate products of REFC (REFC liquids). Thick magenta line denotes crustal rock assimilation combined with fractional crystallization $(A F C)$ model. Magenta star is the possible composition of assimilated rocks (sample OG-74). The model utilizes bulk partition coefficients published in Portnyagin et al. (2015), which is based on Bindeman et al. (1998) and O'Neill and Jenner (2012) compilations
However $D_{\mathrm{CaO}}{ }^{\mathrm{O} / \mathrm{L}}$ could be affected significantly by other factors such as magma $\mathrm{H}_{2} \mathrm{O}$ content (Feig et al. 2006), which will be discussed later. Thus, both FC and mixing trends of $\mathrm{Ca}$ in olivine are not as obvious as $\mathrm{Ni}$ trends.

\section{Pressure estimations}

A two-stage differentiation model for the Gorely magmas (an early stage of high-pressure differentiation 
FC vs. Mixing

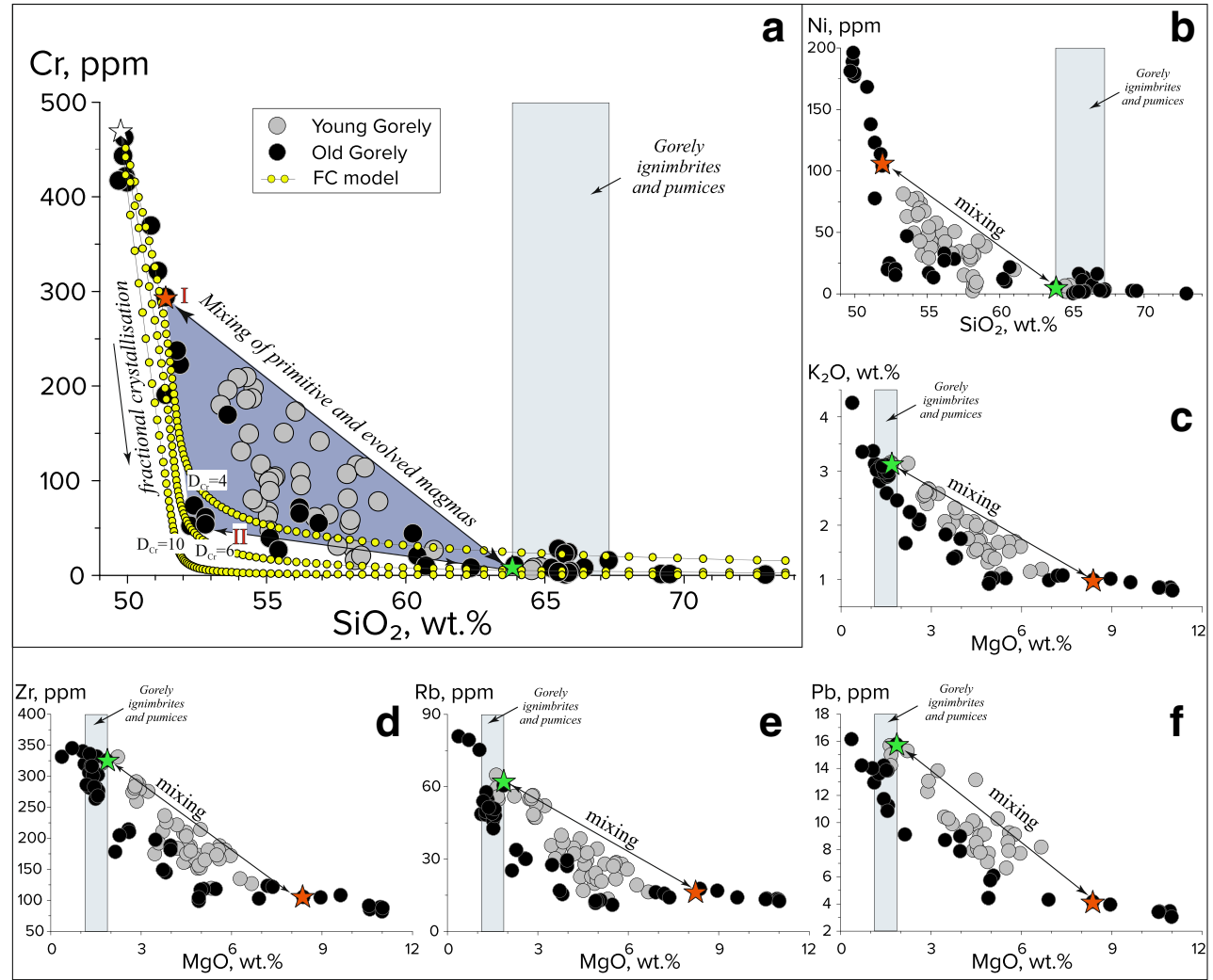

Fig. 11 a Variations in the concentrations of $\mathrm{SiO}_{2}$ and $\mathrm{Cr}$ in lavas and pyroclastic rocks of Gorely volcano. Thin lines with circles show the model trends of fractional crystallization $(F C)$ of basalt melt with initial concentrations of $\mathrm{Cr}=470 \mathrm{ppm}$ and $\mathrm{SiO}_{2}=49.8 \mathrm{wt} \%$ (white star) at various values of the bulk partition coefficient $\mathrm{D}_{\mathrm{Cr}}$ between minerals and melt. The calculations were made using the dependence between the $\mathrm{SiO}_{2}$ concentration and degree of crystallization, according to (Brophy 2008). The Old Gorely compositions lie mostly on the modeled FC trend, while the Young Gorely compositions follow both on mixing and FC trends. Heavy arrows show possible mixing trends of a differentiated dacitic magma (green star) and (I) primitive basalt (red star), and (II) basaltic andesite obtained by $35 \%$ crystallization of primitive melt. Similar FC versus mixing examples on diagrams Ni (b), $\mathrm{K}_{2} \mathrm{O}(\mathbf{c}), \mathrm{Zr}(\mathbf{d}), \mathrm{Rb}(\mathbf{e})$, and $\mathrm{Pb}$ (f) versus indexes of differentiation. Light gray bar at the plots demonstrates the range of compositions of calderaforming eruptions (ignimbrites and pumices). Red and green stars indicate the possible magma mixing end members - basaltic and dacitic magmas correspondingly at $600-800 \mathrm{MPa}$ and a second stage of differentiation at 100-150 MPa), similar to that proposed by Annen et al. (2006), is a possible mechanism to explain Gorely rock evolution trends. Here we test the two-stage differentiation model for Gorely using pressure estimations combined with modeling.

\section{Gorely magma chamber (shallow) pressure}

The low oxygen isotopes of ignimbrites (Seligman et al. 2014) indicate a need for a shallow magma chamber, at least during the caldera formation. Here we attempt to use different methods to confirm the existence of shallow magmatic system.

Since clinopyroxene crystallization is very sensitive to pressure (e.g., Danyushevsky et al. 1996), the existence of primitive (Mg\# $\leq 90)$ clinopyroxene phenocrysts demonstrates deep $(\sim 40 \mathrm{~km}, \sim 1.2 \mathrm{GPa})$ crystallization of parental magma (for example Klyuchevskoy volcano-Ozerov 2000; Auer et al. 2009; Levin et al. 2014). Thus, the higher the pressure, the earlier clinopyroxene appears on the liquidus. $\mathrm{Mg} \#_{78}$ is the most primitive Cpx from Gorely lavas (Fig. 6 and Chashchin and Martynov 2011; Seligman et al. 2014), which requires Cpx crystallization at a much shallower depth.

For pressure estimation, we used an empirical method based on the difference between $\mathrm{Ol}$ and $\mathrm{Cpx}$ liquidus temperatures (Danyushevsky et al. 1996; Danyushevsky 2001) with an accuracy of $\pm 100 \mathrm{MPa}$. The method relies on the fact that pressure increases the crystallization temperature of clinopyroxene much more than the crystallization temperature of olivine. The greater the difference between the calculated 1-atm crystallization temperatures for olivine and clinopyroxene, the greater the crystallization pressure. We used whole-rock analyses of aphyric/subaphyric rocks from Gorely (which are considered to be most similar to the liquid line of descent) with $\mathrm{MgO}$ contents around $5 \mathrm{wt} \%$ (at this point both $\mathrm{Ol}$ and $\mathrm{Cpx}$ are at liquidus; Fig. 4). 


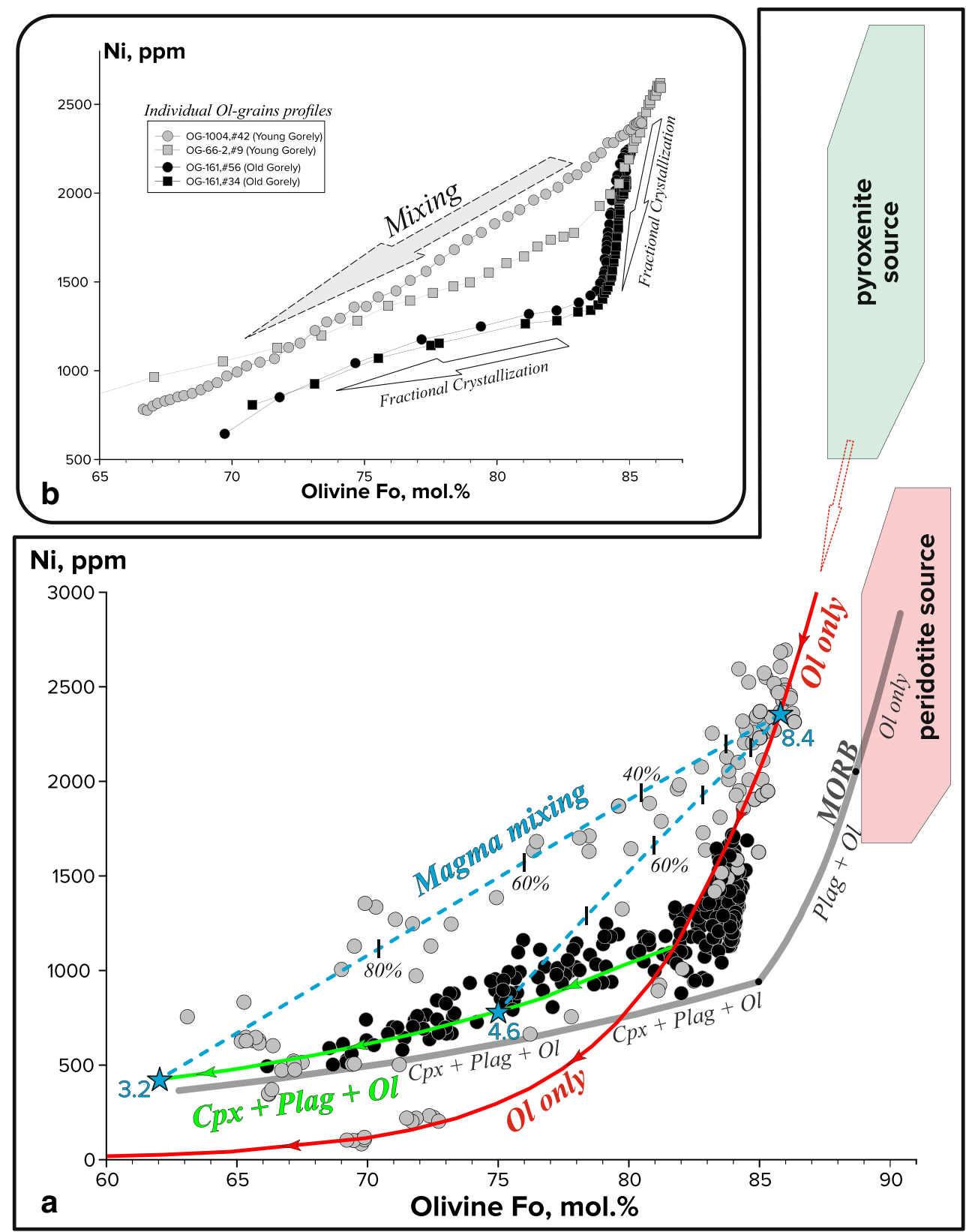

Fig. 12 Variations in the concentrations of $\mathrm{Ni}$ (versus Fo\#) in olivine from rocks of Old Gorely and Young Gorely structural units (highprecision analyses from Table S8). a High-precision olivine analyses from several samples: OG-700, OG-701, OG-704 (Old Gorely) and OG-57, OG-66 (Young Gorely). The solid lines show the fractional crystallization (FC) trends: red line is olivine-only fractionation trend modeled for Gorely magmas with the help of Petrolog3; green line is $\mathrm{Cpx}+\mathrm{Plag}+\mathrm{O} 1$ trend for shallow evolution of Gorely magmas (modeled with the help of Petrolog3); thick light gray line is for reference (from Herzberg et al. 2016) - demonstrates variation of $\mathrm{Ni}$ in MORB olivines during the fractionation of different mineral phases $(\mathrm{Ol}$ only, $\mathrm{Ol}+\mathrm{Plag}, \mathrm{Cpx}+\mathrm{Plag}+\mathrm{Ol})$. The dashed blue lines show examples

Estimations range from 160 to $450 \mathrm{MPa}$ with an average value of $300 \pm 40 \mathrm{MPa}$ (Table 1). That pressure corresponds to a depth of about $10 \mathrm{~km}$, which is consistent with geophysical data for Gorely magma chamber depths $(2-10 \mathrm{~km}$ of the modeled magma mixing trends between primitive and evolved melts (blue stars with blue numbers, which show the concentrations of $\mathrm{MgO}$ in melt, in wt\%), which might explain variations of $\mathrm{Ni}$ in some Young Gorely olivines. The fields of both pyroxenite and peridotite olivines are from Ruprecht and Plank (2013). b Clearer FC and mixing trends could be seen if we use individual olivine grain profiles: two grains from Old Gorely (sample OG-161); two grains from Young Gorely (samples OG-66, OG-1004) rocks. The variations of Ni in Gorely olivines demonstrate a domination of FC processes for Old Gorely magmas versus a combination of magma mixing and FC processes for Young Gorely magmas

after Selyangin and Ponomareva 1999). This suggests that significant amounts of $\mathrm{Cpx}$ and $\mathrm{Pl}$ start to crystallize when mafic magma enters into a Gorely magma chamber at a depth of about $10 \mathrm{~km}$. 

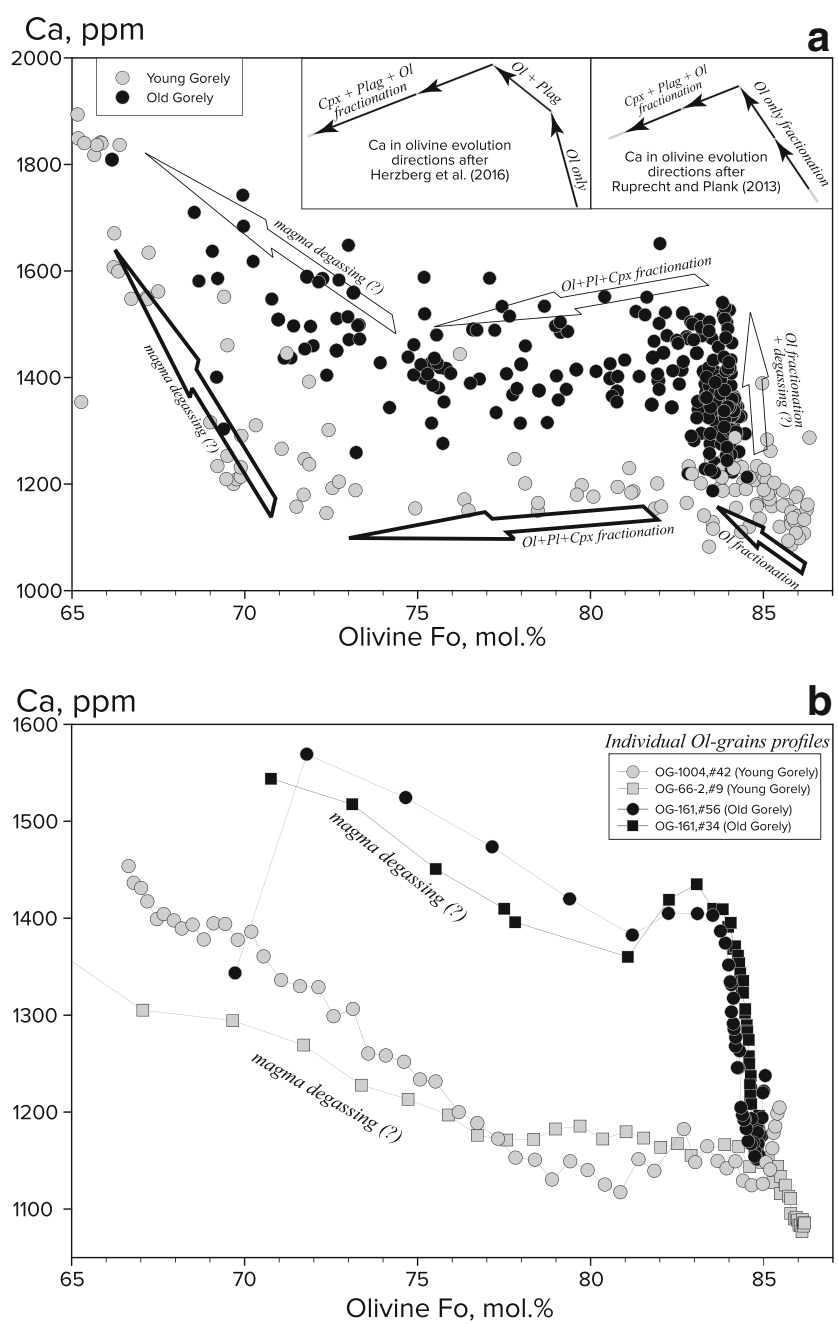

Fig. 13 a Concentration of $\mathrm{Ca}$ in olivine phenocrysts of Gorely volcano rocks versus Fo\# as an index of differentiation. Both Old and Young Gorely rocks follow similar directions of evolution, but at different $\mathrm{Ca}$ levels (Old Gorely olivine have 200-300 ppm more Ca than Young Gorely olivines for given Fo\#), which is consistent with WR data. However, $\mathrm{Ca}$ is increasing in olivines at later stages of evolution (< $\sim \mathrm{Fo}_{75}$ ), which is not consistent with either $\mathrm{FC}$ trends (after Ruprecht and Plank 2013; Herzberg et al. 2016) or Gorely WR data (CaO is decreasing in magma during FC). The increasing of $\mathrm{Ca}$ in olivine could be explained by magma $\mathrm{H}_{2} \mathrm{O}$ loss (degassing), which is proposed by Feig et al. (2006). b Ca trends as observed in individual olivine grain profiles

\section{Pressure estimations for Gorely parental magmas}

Our estimation for Gorely parental magma compositions is based on the assumption that it is in equilibrium with $\mathrm{Fo}_{90}$ olivine. The magma composition was modeled by adding equilibrium olivine to a Gorely basalt composition incrementally, taking into account $\mathrm{Fe}^{3+}(\mathrm{QFM}+1.5)$ and using Toplis (2005) $\mathrm{K}_{\mathrm{d}}$ for the $\mathrm{Fe}^{2+} / \mathrm{Mg}$ exchange, until the melt is in equilibrium with mantle olivine ( $\left.\mathrm{Fo}_{90}\right)$.

The calculated Gorely parental magma composition $(\mathrm{MgO} \approx 12.3 \mathrm{wt} \%)$ was used in the Lee et al. (2009) barometer based on Si activity in melts saturated with orthopyroxene + olivine. The barometer has an uncertainty $\pm 0.2 \mathrm{GPa}$ or about $7 \mathrm{~km}$ of depth. Adding $1.0 \mathrm{wt} \%$ water decreases the depth estimate by $0.7 \mathrm{~km}$, so error related to water content is negligible. Increasing the oxygen fugacity from QFM to NNO reduces estimated depths by about $3.5 \mathrm{~km}$. According to the Lee et al. (2009) barometer, Gorely parental melts form at 1.1 $\pm 0.2 \mathrm{GPa}$, corresponding to $40 \pm 7 \mathrm{~km}$, which matches the mantle-crust boundary below Gorely volcano (Fig. 1c).

\section{Estimation of $\mathrm{H}_{2} \mathrm{O}$ content in Gorely magmas}

The water content of Gorely magmas is not well studied. The traditional technique to estimate magmatic $\mathrm{H}_{2} \mathrm{O}$ content is to measure melt inclusions (e.g., Portnyagin et al. 2007b; Mironov and Portnyagin 2011; Mironov et al. 2015), but the only Gorely melt inclusion study (Tolstykh et al. 2012) did not report any estimation of Gorely magma's $\mathrm{H}_{2} \mathrm{O}$ content. Since there are no melt inclusion data for Gorely, we estimated the $\mathrm{H}_{2} \mathrm{O}$ concentration using three independent techniques (Table 2).

\section{Tholeiitic Index}

The Tholeiitic Index (THI) strongly correlates with magma $\mathrm{H}_{2} \mathrm{O}$ content. Zimmer et al. (2010) estimated water using the equation $\mathrm{H}_{2} \mathrm{O}(\mathrm{wt} \%)=\exp [(1.26-\mathrm{THI}) / 0.32]$ with the uncertainty $\pm 1.2 \mathrm{wt} \%$. When this is applied to Gorely whole-rock analyses, it gives $2.8( \pm 1.2) \mathrm{wt} \%$ of $\mathrm{H}_{2} \mathrm{O}$ for Gorely magmas.

\section{$\Delta$ T Ol-Plag}

This method uses the difference between $\mathrm{Ol}$ and Plag liquidus temperatures (Danyushevsky et al. 1996; Danyushevsky 2001) and allows one to estimate magma $\mathrm{H}_{2} \mathrm{O}$ content with an accuracy of $\pm 0.29 \mathrm{wt} \%$. For this calculation, we used Gorely whole-rock analyses of aphyric/subaphyric rocks, which are considered to approximate liquid compositions, with $\sim 5 \mathrm{wt} \% \mathrm{MgO}$ (at this point, both $\mathrm{Ol}$ and Plag start to appear on the liquidus). Using Petrolog3 software (Danyushevsky and Plechov 2011), magma $\mathrm{H}_{2} \mathrm{O}$ content estimation was calculated for seven aphyric basalt compositions (Table 1). The average magma water content is $\sim 3 \pm 0.2 \mathrm{wt} \%$ (at $\mathrm{MgO} \sim 5.1 \mathrm{wt} \%$ ).

\section{$\Delta T$ dry-wet Ol crystallization}

Water suppresses the crystallization temperature of silicate phases to different extents (e.g., Danyushevsky 2001, Almeev et al.2007). The comparison of measured temperature of olivine crystallization with the crystallization in dry conditions (e.g., Ford etal. 1983 model) allows estimation of the amount of water required to decrease the crystallization temperature.

In order to estimate olivine crystallization temperatures for both Old and Young Gorely, we used the technique based on 
Table 1 Pressure and magma $\mathrm{H}_{2} \mathrm{O}$ content estimations based on Danyushevsky et al. (1996) and Danyushevsky (2001) for seven Old Gorely wholerock compositions

\begin{tabular}{|c|c|c|c|c|c|c|c|c|c|c|c|c|c|}
\hline $\begin{array}{l}\text { Sample } \\
\text { name }\end{array}$ & Reference & $\mathrm{SiO}_{2}$ & $\mathrm{TiO}_{2}$ & $\mathrm{Al}_{2} \mathrm{O}_{3}$ & $\mathrm{FeO}$ & $\mathrm{MnO}$ & $\mathrm{MgO}$ & $\mathrm{CaO}$ & $\mathrm{Na}_{2} \mathrm{O}$ & $\mathrm{K}_{2} \mathrm{O}$ & $\mathrm{P}_{2} \mathrm{O}_{5}$ & $\begin{array}{l}\mathrm{P}, \mathrm{MPa} \\
\pm 100 \mathrm{MPa}\end{array}$ & $\begin{array}{l}\mathrm{H}_{2} \mathrm{O}, \mathrm{wt} \% \\
\pm 0.29 \mathrm{wt} \%\end{array}$ \\
\hline OG-12 & This work & 52.39 & 1.25 & 17.22 & 9.30 & 0.18 & 5.08 & 9.88 & 3.25 & 1.02 & 0.43 & 163.40 & 3.09 \\
\hline OG-14 & This work & 52.26 & 1.28 & 17.25 & 9.49 & 0.18 & 4.98 & 9.82 & 3.31 & 1.03 & 0.41 & 169.80 & 3.08 \\
\hline N79 & Duggen et al. 2007 & 52.81 & 1.25 & 17.20 & 9.65 & 0.18 & 4.92 & 9.23 & 3.50 & 0.92 & 0.34 & 287.10 & 2.99 \\
\hline SG-261 & $\begin{array}{l}\text { Chashchin and Martynov } \\
2011\end{array}$ & 52.63 & 1.27 & 16.76 & 10.47 & 0.18 & 5.14 & 8.89 & 3.39 & 0.96 & 0.31 & 396.60 & 2.45 \\
\hline YuM-2212 & $\begin{array}{l}\text { Chashchin and Martynov } \\
2011\end{array}$ & 51.08 & 1.32 & 18.27 & 9.57 & 0.17 & 5.29 & 9.78 & 3.02 & 1.00 & 0.50 & 347.80 & 3.85 \\
\hline YuM-2166 & $\begin{array}{l}\text { Chashchin and Martynov } \\
2011\end{array}$ & 52.51 & 1.22 & 17.17 & 10.46 & 0.02 & 5.26 & 8.91 & 3.25 & 0.87 & 0.34 & 451.40 & 2.65 \\
\hline \multirow[t]{6}{*}{ YuM-2164 } & $\begin{array}{l}\text { Chashchin and Martynov } \\
2011\end{array}$ & 52.24 & 1.26 & 17.01 & 10.39 & 0.19 & 5.04 & 9.25 & 3.33 & 0.89 & 0.39 & 298.10 & 2.84 \\
\hline & Average & 52.27 & 1.26 & 17.27 & 9.90 & 0.16 & 5.10 & 9.39 & 3.29 & 0.95 & 0.39 & 302.03 & 2.99 \\
\hline & St.Dev. & 0.57 & 0.03 & 0.47 & 0.51 & 0.06 & 0.14 & 0.43 & 0.15 & 0.06 & 0.06 & 108.24 & 0.44 \\
\hline & $\%$ St.Dev. & $1.08 \%$ & $2.50 \%$ & $2.73 \%$ & $5.19 \%$ & $39.50 \%$ & $2.75 \%$ & $4.58 \%$ & $4.54 \%$ & $6.64 \%$ & $16.41 \%$ & $35.84 \%$ & $14.86 \%$ \\
\hline & St. error $(1-\sigma)$ & 0.21 & 0.01 & 0.18 & 0.19 & 0.02 & 0.05 & 0.16 & 0.06 & 0.02 & 0.02 & 40.91 & 0.17 \\
\hline & $\%$ St. error $(1-\sigma)$ & $0.41 \%$ & $0.95 \%$ & $1.03 \%$ & $1.96 \%$ & $14.93 \%$ & $1.04 \%$ & $1.73 \%$ & $1.72 \%$ & $2.51 \%$ & $6.20 \%$ & $13.54 \%$ & $5.62 \%$ \\
\hline
\end{tabular}

The WR analyses (normalized to $100 \%$ anhydrous) are from aphyric/subaphyric basalts and basaltic andesites (a WR analysis of an aphyric rock is close to a liquid composition), with $\mathrm{MgO}$ content close to $\sim 5 \mathrm{wt} \%$ ( $\mathrm{Pl}$ and $\mathrm{Cpx}$ starts to fractionate around this point in Old-Gorely magmas). The averaged point corresponds to $5.1 \mathrm{wt} \% \mathrm{MgO}, 300 \mathrm{MPa}$, and $3 \mathrm{wt} \%$ of $\mathrm{H}_{2} \mathrm{O}$

the $\mathrm{K}_{\mathrm{d}}$ of $\mathrm{Al}_{2} \mathrm{O}_{3}$ in coexisting olivine and spinel (Wan et al. 2008). The reported accuracy of the method is $\pm 22^{\circ} \mathrm{C}$. Olivine host compositions, coexisting spinel inclusions, and calculated temperatures (Wan et al. 2008) for two Gorely basalts ( 9 points for OG-66 and 9 points for OG-160) are given in Table S7. The temperatures vary from 1123 to $1180{ }^{\circ} \mathrm{C}$ for OG-160 (average $1162 \pm 6^{\circ} \mathrm{C}$ ) and $1131-1218{ }^{\circ} \mathrm{C}$ for OG-66 (average $1177 \pm 11{ }^{\circ} \mathrm{C}$ ).

Figure 14 shows the Gorely temperature estimates versus the modeled lines, which reflect the effect of $\mathrm{H}_{2} \mathrm{O}$ content on olivine crystallization temperature. The olivine temperatures are from Ford et al.(1983) and the $\mathrm{H}_{2} \mathrm{O}$ influence on Ol crystallization is from Almeev et al. (2007). The individual temperature estimations are scattered, but the average values for each sample are consistent with $\mathrm{H}_{2} \mathrm{O} \approx 3 \mathrm{wt} \%$.

Those estimations are independent and based on completely different techniques (see magma $\mathrm{H}_{2} \mathrm{O}$ content estimations summary in Table 2). However, all reported data demonstrate that Gorely magmas had about $3 \mathrm{wt} \%$ of $\mathrm{H}_{2} \mathrm{O}$.

\section{Oxygen fugacity conditions for the Gorely magmas}

For the oxidation state, Kelley and Cottrell (2009) suggest that arc magmas are intrinsically more oxidized than MORB. According to that work, $\mathrm{Fe}^{3+} / \Sigma \mathrm{Fe}$ might be calculated through the water content from the equation $\mathrm{Fe}^{3+} / \Sigma \mathrm{Fe}=0.026 \mathrm{H}_{2} \mathrm{O}+$ 0.14 (for subduction magmas). For basaltic Gorely magmas that have $\sim 3 \mathrm{wt} \%$ estimated $\mathrm{H}_{2} \mathrm{O}$ (see section "Estimation of $\mathrm{H} 2 \mathrm{O}$ content in Gorely magmas" above), the $\mathrm{Fe}^{3+} / \Sigma \mathrm{Fe}$ value is 0.22 , which corresponds to oxygen fugacity $1.2 \log$ units above the QFM buffer (Kress and Carmichael 1988).

This $\mathrm{fO}_{2}$ estimation $(\mathrm{QFM}+1.2)$ is consistent with evaluations based on Cu-systematics (Lee et al. 2012), which is illustrated on Fig. 15b. However, methods based on compositions of a mineral pair's coexistence are sensitive to oxygen fugacity (Ballhaus et al. 1990, Andersen and Lindsley 1988) and produce higher $\log \mathrm{fO}_{2}$ values (Fig. 15a). Chashchin and Martynov (2011) reported Gorely $\mathrm{fO}_{2}$ data calculated from a magnetite-ilmenite oxybarometer (after Buddington and Lindsley 1964). The data are scattered in a wide range around $\sim$ QFM +1.5 (Fig. 15a). Our
Table 2 Gorely volcano magma $\mathrm{H}_{2} \mathrm{O}$ content estimations using different methods

\begin{tabular}{llll}
\hline & $\mathrm{H}_{2} \mathrm{O}, \mathrm{wt} \%$ & St. error, wt $\%$ & Method \\
\hline 1 & 2.8 & \pm 1.2 & Zimmer et al. (2010) \\
2 & 3.0 & \pm 0.3 & Danyushevsky et al. (1996) \\
3 & $\sim 3.0$ & & Almeev et al. (2013) + Wan et al. (2008) \\
& 2.2 & \pm 0.1 & Average for Kamchatka volcanoes (Portnyagin et al. 2007a, b) \\
\hline
\end{tabular}

Average parental magma $\mathrm{H}_{2} \mathrm{O}$ content for Kamchatka volcanoes (Portnyagin et al. 2007a, b) for reference 


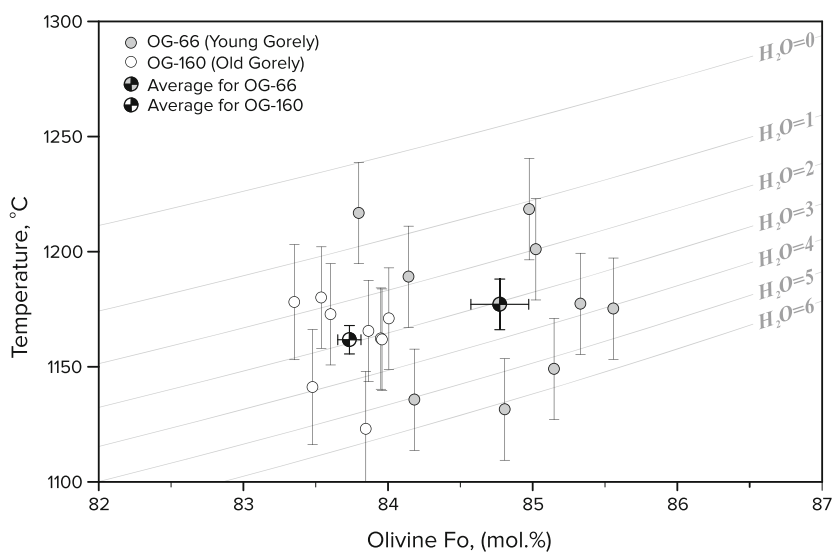

Fig. 14 Gorely magma $\mathrm{H}_{2} \mathrm{O}$ content estimations based on Ol-Sp pairs (after Wan et al. 2008) for samples OG-160 (Old Gorely) and OG-66 (Young Gorely). Model $\mathrm{H}_{2} \mathrm{O}$ (in wt $\%$ ) lines reflect the effect of water on olivine crystallization temperature (Ford et al. 1983 model combined with Almeev et al. 2007 data with the help of Petrolog3 software). The individual temperature estimations (nine measurements per sample, see Table S7) are scattered, but the average values for every sample $\left(1162{ }^{\circ} \mathrm{C}\right.$ for OG-160 and $1177^{\circ} \mathrm{C}$ for OG-66) are consistent with $\mathrm{H}_{2} \mathrm{O} \approx 3 \mathrm{wt} \%$

own $\mathrm{fO}_{2}$ estimations based on Ol-Sp compositions (after Ballhaus et al. 1990) are $\sim \mathrm{QFM}+1.8$ (see Table S7 and Fig. 15a). Based on all estimations described above, we assume an average of log $\mathrm{fO}_{2}=\mathrm{QFM}+1.5$ for Gorely magma evolution modeling.

\section{FC modeling + degassing}

The simulation of fractional crystallization was performed in Petrolog ver. 3.1.1.3 software (Danyushevsky and Plechov 2011) using models of Danyushevsky (2001) for the determination of the liquidus temperatures and compositions of olivine, clinopyroxene, and plagioclase. The model of Ariskin and Barmina (1999) was used for Fe-oxides, and the model of Kress and Carmichael (1988) was used for the $\mathrm{Fe}^{2+} / \mathrm{Fe}^{3+}$ ratio of the melt. The other crystallization parameters were as follows: magma $\mathrm{H}_{2} \mathrm{O}$ content $=3 \mathrm{wt} \%$ and the $\mathrm{fO}_{2}=\mathrm{QFM}+1.5$. Pressure values were changed in different models in order to have the best fit to the actual data.

\section{Deep magma evolution modeling}

According to our pressure estimations, Gorely's parental magmas $\left(\mathrm{MgO} \approx 12.3 \mathrm{wt} \%\right.$, in equilibrium with $\mathrm{Fo}_{90}$ ) formed at $\sim 1.1 \mathrm{GPa}$. However, this pressure is too high for just olivine fractionation (which is observed on earlier stages of Gorely magma evolution), since Cpx crystallization is very sensitive to pressure (Danyushevsky et al. 1996). Thus, only magma evolution under strong decompression conditions could suppress early $\mathrm{Cpx}$ fractionation. The modeling of Gorely parental magma crystallization confirms that. Only if we use a strong decompression condition while magma evolved (pressure and temperature decrease rate is $3.6 \mathrm{MPa} /{ }^{\circ} \mathrm{C}$ ), we could suppress $\mathrm{Cpx}$ crystallization until the Gorely magma evolves to $\mathrm{MgO}=5 \mathrm{wt} \%$ (Fig. 16).

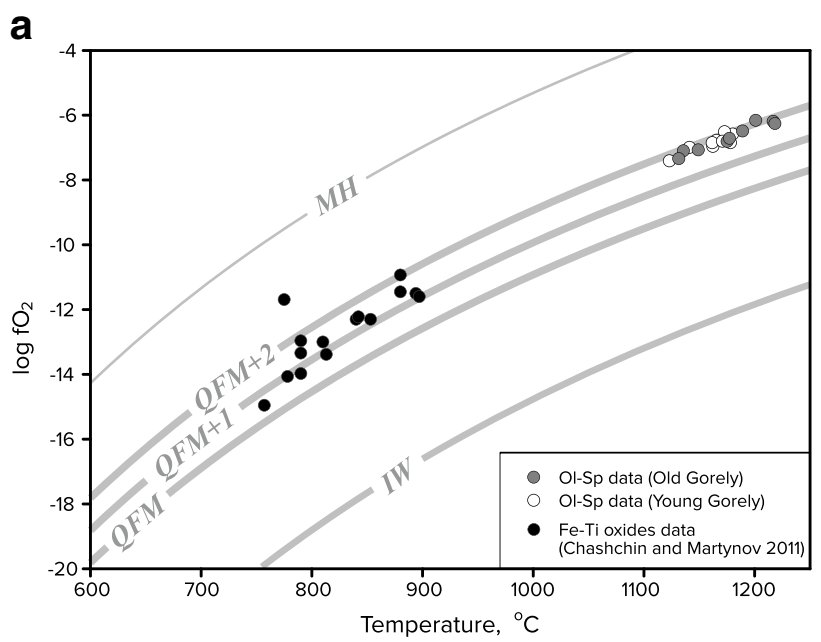

b

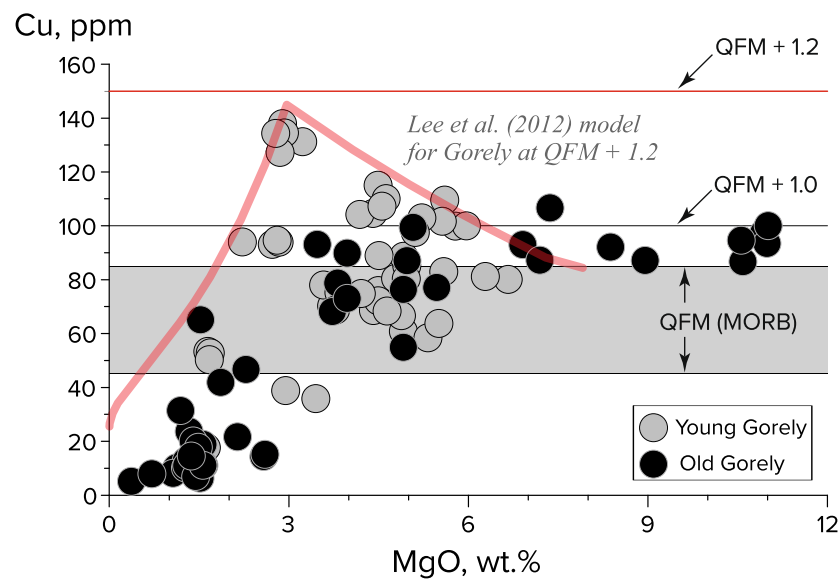

Fig. 15 a Thermo-oxybarometry of Gorely volcanic rocks: log oxygen fugacity $\left(\log \mathrm{fO}_{2}\right)$ versus temperature, estimated from: (1) Mt-Ilm equilibria (Buddington and Lindsley 1964) reported in Chashchin and Martynov (2011); (2) olivine-spinel equilibria (Ballhaus et al. 1990) reported in this work (see Table S7). The compositions of olivine and spinel and calculated values of $\mathrm{T}$ and $\mathrm{fO}_{2}$ are given in Table S7. The thickness of the oxygen buffer curves ( $Q F M$ quartz-fayalite-magnetite, $M H$ magnetite-hematite, $I W$ iron-wüstite) corresponds to pressure variations of a particular oxygen buffer between $1 \mathrm{~atm}$ and $500 \mathrm{MPa}$. b Gorely rocks WR compositions on $\mathrm{Cu}$ versus $\mathrm{MgO}$ plot that illustrates the Lee et al. (2012) method to estimate oxygen fugacity (see details in text)

\section{Magma chamber FC modeling}

Our estimations of such magma chamber evolution parameters as pressure (300 MPa), magma $\mathrm{H}_{2} \mathrm{O}$ content ( $\left.\sim 3 \mathrm{wt} \%\right)$, and $\log \mathrm{fO}_{2}$ (QFM+1.5 log units) allow us to model FC processes in the Gorely magma chamber (Fig. 16). It is obvious that high pressure (500 and $800 \mathrm{MPa}$ ) models do not fit the actual data (mostly because of earlier Cpx fractionation and suppression of Plag and $\mathrm{Mt}$ fractionation). The low pressure models $(50,100$, and $300 \mathrm{MPa})$ fit the actual data much better $\left(\mathrm{CaO}, \mathrm{FeO} *, \mathrm{TiO}_{2}\right.$ plots $)$, which is compatible with our pressure estimations $(300 \mathrm{MPa})$ and previous modeling results (100 MPa from Seligman et al. 2014). The $50 \mathrm{MPa}$ line fits well for most elements, except for $\mathrm{Al}_{2} \mathrm{O}_{3}$ and 
Fig. 16 Several illustrative plots with modeling results compared with actual WR data. Red dashed line demonstrates deep decompression (from 1.1 GPa to $300 \mathrm{MPa}$ ) and $\mathrm{Ol}+\mathrm{Sp}$ fractionation. Different colored lines with triangles are the models of magma chamber $\mathrm{FC}$ at different pressures (from 50 to $800 \mathrm{MPa}$ )
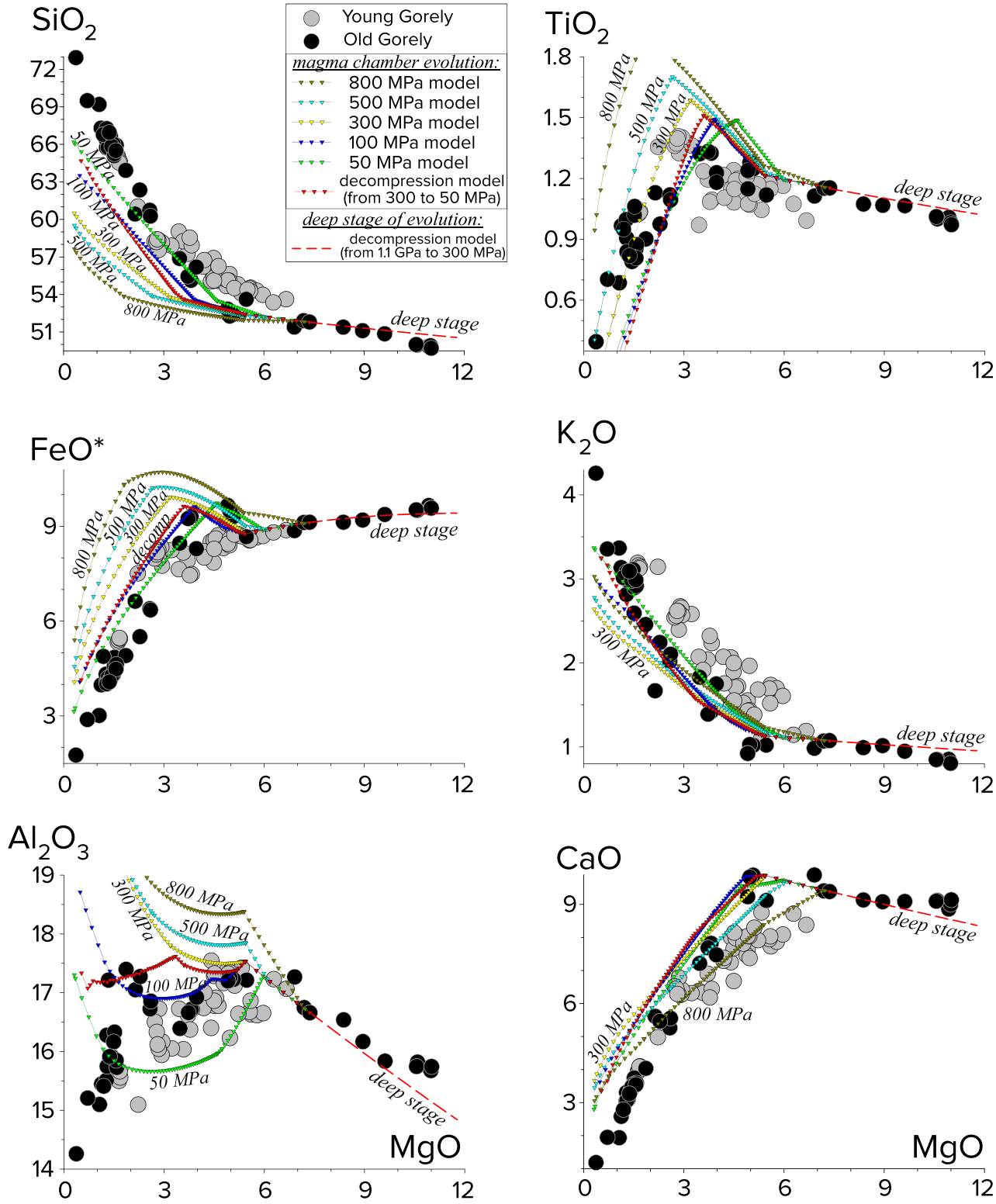

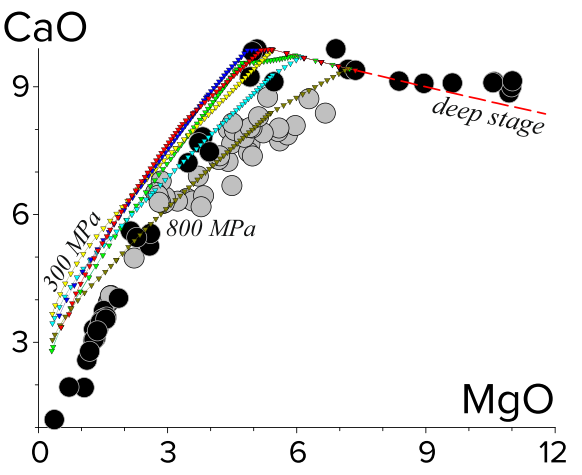

$\mathrm{TiO}_{2}$. Pressure as high as $300 \mathrm{MPa}$ is not enough to crystallize a sufficient amount of Plag, Ol, and Mt. The $100 \mathrm{MPa}$ model is probably the best fit of the isobaric (constant pressure) models. However, the decompression model (pressure changes from 300 to $50 \mathrm{MPa}$ during the magma evolution), which is consistent with Gorely magma chamber depths ( 2 to $10 \mathrm{~km}$ ), fits slightly better on all plots. All magma chamber model lines behave oddly on the $\mathrm{Al}_{2} \mathrm{O}_{3}$ plot, which reflects Plag fractionation. All pressure models demonstrate weak Plag fractionation, especially in evolved $(\mathrm{MgO}<3 \mathrm{wt} \%)$ magmas.

Plag fractionation is not only pressure dependent but also is affected strongly by magma $\mathrm{H}_{2} \mathrm{O}$ content (e.g., Danyushevsky 2001). The possible explanation of the observed strong Plag fractionation, which is not modeled well enough in Gorely volcano case, is potentially high rate of degassing (water loss).
Moreover, the rates of degassing (controlled by decompression) might be not uniform (as a modeling software assumes).

\section{Degassing $\left(\mathrm{H}_{2} \mathrm{O}\right.$ loss $)$}

According to the FC model, $\mathrm{H}_{2} \mathrm{O}$ (as an incompatible element) should be accumulated in magma during $\mathrm{FC}$ (Fig. 17). $\mathrm{H}_{2} \mathrm{O}$ accumulation would suppress Plag fractionation in sufficient amounts. However, the petrography of rocks (numerous Plag phenocrysts in intermediate rocks) combined with $\Delta \mathrm{T}$ OlPlag calculations (after Danyushevsky 2001) for compositions of aphyric/subaphyric Old Gorely rocks are not consistent with a $\mathrm{H}_{2} \mathrm{O}$ accumulation model (Fig. 17). We propose water loss (degassing) from the Gorely magma chamber, which could explain the strong Plag fractionation in Gorely's 


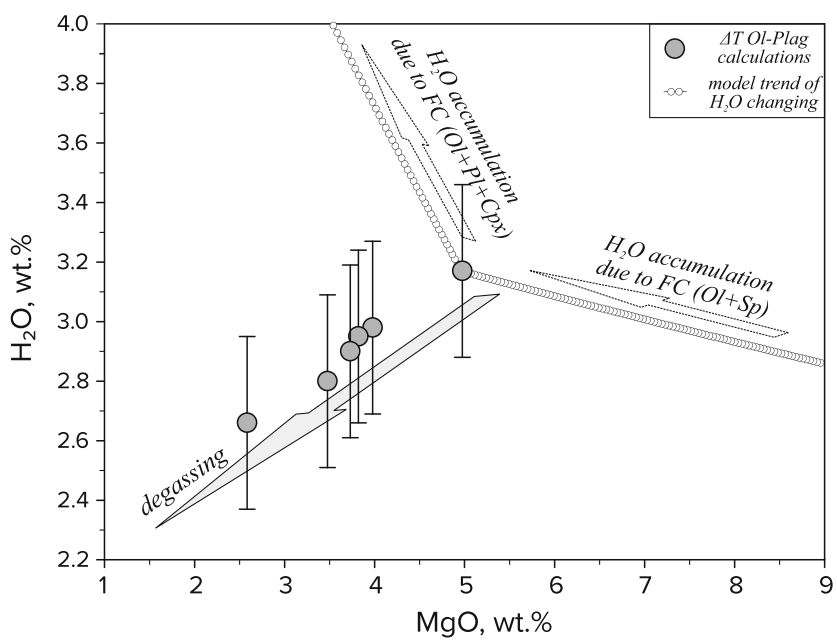

Fig. 17 Old Gorely magma $\mathrm{H}_{2} \mathrm{O}$ content variations during magma evolution. $\mathrm{H}_{2} \mathrm{O}$ behaves as an incompatible element and should accumulate in the magma during fractional crystallization (thin model line with small white circles). However, $\Delta \mathrm{T}$ Ol-Plag calculations (after Danyushevsky 2001) for compositions of aphyric/subaphyric Old Gorely rocks (large gray circles) demonstrate a water loss (degassing) trend. The $\Delta \mathrm{T}$ Ol-Plag calculations were made for the following samples: OG-14, OG-71, OG-73, OG-6A, OG-64

intermediate and silicic rocks, as suggested by both petrography (Fig. S1) and WR data $\left(\mathrm{Al}_{2} \mathrm{O}_{3}\right.$ plot of Fig. 16).

One more line of evidence of $\mathrm{H}_{2} \mathrm{O}$ loss via degassing in Gorely magmas is the behavior of $\mathrm{CaO}$ in olivine (Fig. 13). The concentration of $\mathrm{Ca}$ in olivine depends on $\mathrm{Ca}$ content of the surrounding magma, but $\mathrm{Ca}$ partitioning also is strongly affected by $\mathrm{H}_{2} \mathrm{O}$ content in the magma (Feig et al. 2006; Gavrilenko et al. 2016). The higher the water concentration in the magma, the lower the Ca-concentration in equilibrium olivine (Feig et al. 2006). This water effect on $D_{\mathrm{CaO}} \mathrm{O} / \mathrm{L}$ was calibrated in Gavrilenko et al. (2016) based on both experimental and melt inclusion studies. Gorely olivines demonstrate strongly increasing $\mathrm{Ca}$ content during magma evolution (expressed as Fo in Fig. 13) that is not consistent with wholerock data $(\mathrm{CaO}$ decreases in magmas along the entire range of compositions, except for the most primitive ones). The only plausible explanation for decreasing concentrations of $\mathrm{CaO}$ in Gorely olivines is degassing-induced water loss, which would affect the Ca partitioning (Ol-melt).

Thus, the proposed degassing-induced water loss would increase Plag fractionation significantly that could improve not only the model lines on main Plag plot $\left(\mathrm{Al}_{2} \mathrm{O}_{3}\right.$ plot on Fig. 16) but also $\mathrm{SiO}_{2}$ and $\mathrm{CaO}$ plots. Unfortunately, any of our pressure models (Fig. 16) do not demonstrate the same degassing rate that is observed on Fig. 17. Most likely, the real decompression rate, which mainly control the water loss, is not as uniform as we are able to model by Petrolog3 software. Probably, the magma decompression was much stronger at the bottom parts of Gorely magmatic system, and then it slowed down in the upper parts. Besides, a somewhat similar strong degassing process was suggested for Klyuchevskoy volcano in Mironov and Portnyagin (2011), based on melt inclusion data combined with $\Delta \mathrm{T}$ Ol-Plag calculations.

\section{Gorely caldera collapse and magmatic evolution}

\section{Differences between Old and Young Gorely volcanoes}

Old Gorely volcano experienced a voluminous $\left(\sim 100 \mathrm{~km}^{3}\right)$ caldera-forming eruption that marked the end of Old Gorely and the beginning of Young Gorely (Kirsanov and Melekescev 1991; Selyangin and Ponomareva 1999). Both magma series are genetically related, but according to our studies, the differences are the following (see summary in Table 3): (1) Old Gorely has a wider range of fractionation (49-75 wt $\% \mathrm{SiO}_{2}$ ) than young Gorely $\left(53-65 \mathrm{wt} \% \mathrm{SiO}_{2}\right) ;(2)$ Old Gorely evolved via fractional crystallization with minimal magma mixing, whereas Young Gorely has extensive evidence of magma mixing; and (3) the Old Gorely caldera covers a larger area than the cluster of composite cones that make up most of Young Gorely, suggesting that the calderaforming eruption reduced the diameter of the magma chamber.

Furthermore, there are some changes in the morphology of the volcanic edifices of Old and Young Gorely. According to Kirsanov and Melekescev (1991), the Old Gorely edifice might be interpreted as a "shield like composite volcano" (using the classification of Davidson and de Silva 2000). This morphological type, which has shallow-sloped flanks, common craters in summit region, and greater diversity of magmas, has examples at Newberry (Cascades) and Okmok (Aleutians) volcanoes. The Young Gorely edifice belongs to a "compound composite volcano" (Davidson and de Silva 2000) morphological type, in that it is a large equant massif with limited vent migration.

\section{Gorely magma plumbing system}

Our pressure estimations show that the evolution of Gorely magmas occurs both at shallow $(2-10 \mathrm{~km})$ and at deep $(\sim 40 \mathrm{~km})$ parts of the lithosphere. For the shallow magma chamber, a model of a series of sills seems favorable (e.g., Menand 2008, Gudmundsson 2011). The magma is diverted to sills where it undergoes evolution dominated by fractional crystallization (Fig. 18a). The high aspect ratio (width/height) of a sillshaped magma chamber appears more favorable for fractional crystallization than a spherical or cylindrical magma chamber shape, which appears more favorable for magma mixing processes. The effect of the magma body aspect ratio on the magma mixing process was investigated in Oldenburg et al. (1989), where it was demonstrated that mixing is strongly dependent on aspect ratio and is most efficient in roughly equant magma bodies. Moreover, many closely spaced sills would create slivers of crust surrounded by hot basalt making it easier to 
Table 3 Brief summary of the differences between Old and Young Gorely

\begin{tabular}{lll}
\hline & Old Gorely & Young Gorely \\
\hline Composition of rocks & Wide range (49-75 wt\% SiO2) & Narrow range (53-65 wt\% SiO2) \\
Magma differentiation style & Fractional crystallization & Magma mixing \\
Magma plumbing system & Larger size & Smaller size \\
Morphology & Shield-like composite volcano & Compound composite volcano \\
\hline
\end{tabular}

partially melt the crust and generate dacitic magma (e.g., Smith and Leeman 1987; Atherton and Petford 1993; Tepper et al. 1993; Rapp and Watson 1995; Petford and Atherton 1996; Chappell and White 2001; Izbekov et al. 2004; Simakin and Bindeman 2012; Bindeman and Simakin 2014) for the impending ignimbrite (Seligman et al. 2014). The partial melting of surrounding rocks is confirmed by the isotopic compositions $(\mathrm{Nd}, \mathrm{Sr}, \mathrm{O})$ of Gorely ignimbrites, which have a crustal contamination signature (Seligman et al. 2014). Thus, a "series of sills" model for the Old Gorely shallow plumbing system is favorable because the model explains both FC domination and voluminous dacite production.

For deep magma evolution, the model of a sub-crustal magma reservoir might be interesting, but not necessary. Based on seismological data combined with petrological depth estimations, Levin et al. (2014) describe a model for Klyuchevskoy volcano with the magma accumulation/evolution starting at a deep reservoir (below the crust-mantle boundary) and subsequent decompression evolution during magma ascent through the crust (Ariskin et al. 1995; Almeev et al. 2013). The Klyuchevskoy model does not require a crustal magma chamber. However, in the case of Gorely volcano, which contains much more evolved rocks $\left(75 \mathrm{wt} \% \mathrm{SiO}_{2}\right)$ than Klyuchevskoy volcano (55 wt $\%$ $\mathrm{SiO}_{2}$ ), the "Klyuchevskoy model" would require a huge sub- crustal magma reservoir to generate $100 \mathrm{~km}^{3}$ of dacitic ignimbrite from basalt primarily by FC. According to Brophy (2008), a dacite $\left(\sim 65 \mathrm{wt} \% \mathrm{SiO}_{2}\right)$ could be produced by $\sim 75 \%$ crystallization of a mafic basalt. Thus, for Gorely volcano, we suggest a hybrid model, where a deep part of the magma plumbing system converts mantle-derived picritic basalt into basalt and then the magma rises to form sills at shallow depths (Fig. 18a). Fractional crystallization leaves a lot of olivine at depth and the dacite forms at shallow depths in a series of sills.

\section{Possible edifice collapse effect on magma plumbing system}

Sector collapse and its effect on volcanic activity and the magma plumbing system has been studied worldwide (e.g., Presley et al. 1997, Amelung and Day 2002, Tibaldi 2004, Ginibre and Wörner 2007, Manconi et al. 2009, Longpré et al. 2009). Magma systems may respond to rapid unloading of overburden pressure, due to edifice collapse, with a violent large-scale paroxysmal eruption. At Kamchatka, the eruption of Bezymianny in 1956 serves as a good example of volcanic system where lateral volcanic blast was triggered by volcanic slope failure (Belousov 1996, Shipman et al. 2011). A large-scale collapse, with a volume of tens of cubic kilometers, forces a magmatic plumbing system to adjust to new conditions and can lead to

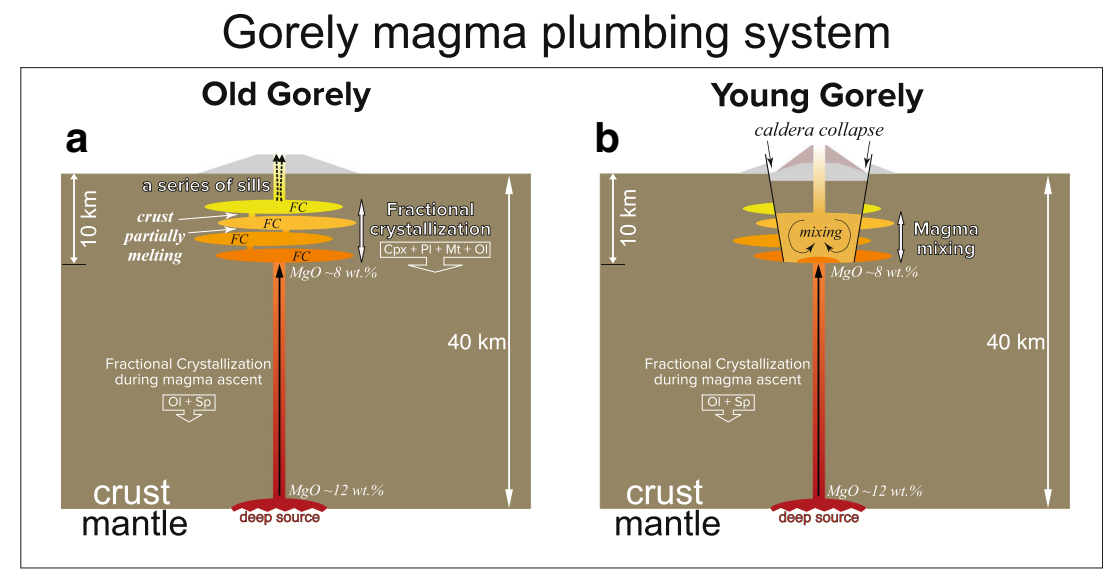

Fig. 18 Illustration for the discussion about the Gorely magma plumbing system. a The model of a magma plumbing system for Old Gorely volcano, which has a shallow magma chamber, represented by a series of sills (e.g., Menand 2008, Gudmundsson 2011) with a minor role of magma mixing (AFC domination) in sill-shaped magma bodies (after Oldenburg et al. 1989); the wall-rock between the sills is partially melted to help produce the dacite. The magmatic system also has deep roots (FC during magma ascent to shallow depths). b The possible model of magma plumbing system for Young Gorely volcano, where a series of sills is deformed by the caldera collapse, producing a more equant shape for the Gorely magmatic system, which is most efficient for magma mixing (after Oldenburg et al. 1989) 
significant changes in the magma transport dynamics and the ways of magma differentiation (e.g., Pinel and Jaupart 2000, 2003, 2005). Gorbach and Portnyagin (2011) and Gorbach et al. (2013) demonstrated a change in magma differentiation for Shiveluch volcano from fractional crystallization to magma mixing, as a result of possible reduction of magma chamber size due to edifice sector collapse and paroxysmal eruption.

In contrast to edifice sector collapse, a caldera collapse has different genetic features (paroxysmal eruption triggers magma chamber roof collapse due to voluminous withdrawal of magma; e.g., Lipman 1997). However, it seems that both sector collapse and caldera collapse processes can make changes in the size and/ or geometry of a magma system, which favor magma mixing.

We propose that caldera collapse changed the differentiation mechanism at Gorely. A voluminous Plinian eruption ( 38$40 \mathrm{ka})$ led to the collapse of Old Gorely because of the withdrawal of silicic magma that formed the extensive pumice fall and ignimbrite deposits $\left(\sim 100 \mathrm{~km}^{3}\right)$ surrounding the volcano (Selyangin and Ponomareva 1999). Our data demonstrate that, in the case of Gorely, the magma plumbing system at shallow depths was changed significantly following the caldera collapse that destroyed the Old Gorely edifice. The changes manifested primarily in modifying the dominant mechanism of magma differentiation: from fractional crystallization before caldera collapse to magma mixing after. If Old Gorely's shallow plumbing system (Fig. 18a) was a series of sills or a series of roughly coaxial disks similar to Eyjafjallajokull volcano (Sigmundsson et al. 2010), then the disruption of the sills and thin wall-rock layers by the magma ejection and caldera collapse would result in a cylindrical-shaped magma chamber directly beneath the vent. The vertically oriented cylindrical magma body, inferred beneath Mount St. Helens via seismicity (Lees 1992; Scandone and Malone 1985), is an appropriate model since that shape is more suitable for magma mixing (Oldenburg et al. 1989). The destruction of the sills allows mixing and consolidation of magma from the different sills and changes the aspect ratio/geometry of the Gorely magma chamber (Fig. 18b). This reorganization of Gorely's magma plumbing system led to changes in the composition of Young Gorely rocks and, perhaps, as a consequence, to different edifice morphology. Thus, the Young Gorely magmafeeding system has the same deep roots with fractional crystallization of mafic parental magmas as Old Gorely, but its shallow magma chamber is more equant and dominated by magma mixing processes (Fig. 18b). A magma plumbing system with similar features (FC at depth and mixing in shallow chamber) was described by Almeev et al. (2013) for Bezymianny volcano (Kamchatka).

This study allows us to suggest that Gorely is not a special case. For instance, at Kamchatka, there are many stratovolcanoes (e.g., Gamchen, Komarov, Bolshoi Semiachik, Opala, Koshelev volcanoes) with shield-like edifices at the basement (Fedotov and Masurenkov 1991), and similar changes in morphology during a volcano's life are noted for other arc volcanoes (e.g., Cascades, Central America); this problem requires additional studies in order to draw conclusions on a global scale.

\section{Conclusions}

The Gorely edifice consists of a calc-alkaline series of rocks spanning the range from high-Mg basalts (most primitive) to rhyolites (most evolved). The series has typical arc rock features such as $\mathrm{Nb}$-Ta depletion and LILE enrichment. The whole set of Gorely geochemical data is divided into two age units, "Old Gorely" and "Young Gorely," separated by voluminous caldera-forming eruptions. Magma evolution occurs in a closed magmatic system (the role of recharge-evacuation processes is negligible) in two steps: (1) deep (1.1 GPa to $300 \mathrm{MPa}) \mathrm{Ol}$ fractionation during magma ascent (decompression conditions) through the crust and (2) shallow magma chamber evolution (300 to $50 \mathrm{MPa}$ ). Fractional crystallization combined with crustal rock assimilation dominates evolution of the Old Gorely rocks, whereas magma mixing is more significant in the Young Gorely eruptives, after the caldera-forming eruptions transformed Gorely's magma-feeding system significantly (Fig. 18). Gorely magmas differentiate in a shallow magma chamber at pressures from 300 to $50 \mathrm{MPa}$ (decompression), $\mathrm{H}_{2} \mathrm{O}$ concentrations $\sim 3 \mathrm{wt} \%$ (followed by $\mathrm{H}_{2} \mathrm{O}$ loss), and log oxygen fugacity between $\mathrm{QFM}+1.2$ to $\mathrm{QFM}+1.8 \log$ units (average $\mathrm{QFM}+1.5)$. All major minerals $(\mathrm{Ol}+\mathrm{Cpx}+\mathrm{Plag}+$ $\mathrm{Mt})$ fractionate in the shallow magma chamber, which is confirmed by modeling (Petrolog3 software). Strong Plag fractionation requires $\mathrm{H}_{2} \mathrm{O}$ removal (degassing) from Gorely magmas.

Acknowledgments We thank Natalia Kononkova for her help with olivine and pyroxene microprobe analyses at Vernadsky Institute of Geochemistry and Analytical Chemistry (Russia). Additionally, we want to thank participants of the NSF PIRE project, particularly John Eichelberger and Pavel Izbekov, for their help in microprobe and whole-rock analyses at the University of Alaska Fairbanks.

MG acknowledges support from International Fulbright Science and Technology, from Graduate School of Rutgers University, New Brunswick, and personally Prof. Claude Herzberg. PRK acknowledges support from the NSF Division of Polar Programs. MG and AN acknowledge support from NSF grant EAR-1015422. MG acknowledges support from the Far East Branch of the Russian Academy of Sciences grants "12III-A-08-166" and "15-I-1-025." AO acknowledges support from the Far East Branch of the Russian Academy of Sciences, grant "15-I-2-069" and Russian Foundation of Basic Research, grant "15-05-05502".

We are especially grateful to Maxim Portnyagin, Angela Seligman, Ilya Bindeman, and three anonymous reviewers for the critical reviews and to Michelle Coombs for the editorial work.

\section{References}

Aiuppa A, Giudice G, Liuzzo M, Tamburello G, Allard P, Calabrese S, Chaplygin I, McGonigle AJS, Taran Y (2012) First volatile inventory for Gorely volcano, Kamchatka. Geophys Res Lett 39(6), L06307. doi:10.1029/2012GL051177 
Almeev RR, Holtz F, Koepke J, Parat F, Botcharnikov RE (2007) The effect of $\mathrm{H}_{2} \mathrm{O}$ on olivine crystallization in MORB: experimental calibration at $200 \mathrm{MPa}$. Am Mineral 92(4):670-674. doi:10.2138/ am.2007.2484

Almeev RR, Kimura JI, Ariskin AA, Ozerov AY (2013) Decoding crystal fractionation in calc-alkaline magmas from the Bezymianny volcano (Kamchatka, Russia) using mineral and bulk rock compositions. J Volcanol Geotherm Res 263:141-171. doi:10.1016/j.jvolgeores. 2013.01.003

Amelung F, Day S (2002) InSAR observations of the 1995 Fogo, Cape Verde, eruption: implications for the effects of collapse events upon island volcanoes. Geophys Res Lett 29(12):47-41-47-44. doi: 10.1029/2001GL013760

Andersen DJ, Lindsley DH (1988) Internally consistent solution models for Fe-Mg-Mn-Ti oxides; Fe-Ti oxides. Am Mineral 73(7-8):714 726

Anderson AT (1976) Magma mixing: petrological process and volcanological tool. J Volcanol Geotherm Res 1(1):3-33. doi:10.1016/03770273(76)90016-0

Annen C, Blundy JD, Sparks RSJ (2006) The genesis of intermediate and silicic magmas in deep crustal hot zones. J Petrol 47(3):505-539. doi:10.1093/petrology/egi084

Arculus RJ (2003) Use and abuse of the terms calcalkaline and calcalkalic. J Petrol 44(5):929-935. doi:10.1093/petrology/44.5.929

Ariskin AA, Barmina GS (1999) An empirical model for the calculation of spinel-melt equilibria in mafic igneous systems at atmospheric pressure: 2. Fe-Ti oxides. Contrib Mineral Petrol 134(2-3):251263. doi: $10.1007 / \mathrm{s} 004100050482$

Ariskin AA, Barmina GS, Ozerov AY, Nielsen RL (1995) Genesis of high-alumina basalts from Klyuchevskoi volcano. Petrology 3(5): 449-472

Atherton MP, Petford N (1993) Generation of sodium-rich magmas from newly underplated basaltic crust. Nature 362(6416):144-146. doi: $10.1038 / 362144 \mathrm{a} 0$

Auer S, Bindeman I, Wallace P, Ponomareva V, Portnyagin M (2009) The origin of hydrous, high- $\delta^{18} \mathrm{O}$ voluminous volcanism: diverse oxygen isotope values and high magmatic water contents within the volcanic record of Klyuchevskoy volcano, Kamchatka, Russia. Contrib Mineral Petrol 157(2):209-230. doi:10.1007/s00410-0080330-0

Avdeiko GP, Savelyev DP, Palueva AA, Popruzhenko SV (2007) Evolution of the Kurile-Kamchatkan volcanic arcs and dynamics of the Kamchatka-Aleutian Junction. In: Volcanism and subduction: the Kamchatka region. American Geophysical Union, p 3755. doi: 10.1029/172GM04

Baboshina VA, Tereschenkov AA, Kharakhinov VV (1984) Deep structure of the Sea of Okhotsk according to geophysical data, overview information. Vsesouzniy Nauchno-Issledovatelskiy Institute (VNII) Gazprom 3:41 (in Russian)

Ballhaus C, Berry RF, Green DH (1990) Oxygen fugacity controls in the Earth's upper mantle. Nature 348(6300):437-440. doi:10.1038/ $348437 \mathrm{a} 0$

Batanova VG, Sobolev AV, Kuzmin DV (2015) Trace element analysis of olivine: high precision analytical method for JEOL JXA-8230 electron probe microanalyser. Chem Geol 419:149-157. doi:10.1016/j. chemgeo.2015.10.042

Belousov A (1996) Deposits of the 30 March 1956 directed blast at Bezymianny volcano, Kamchatka, Russia. Bull Volcanol 57(8): 649-662. doi:10.1007/s004450050118

Bindeman IN, Simakin AG (2014) Rhyolites - hard to produce, but easy to recycle and sequester: integrating microgeochemical observations and numerical models. Geosphere 10(5):930-957. doi:10.1130/ ges00969.1

Bindeman IN, Davis AM, Drake MJ (1998) Ion microprobe study of plagioclase-basalt partition experiments at natural concentration levels of trace elements. Geochim Cosmochim Acta 62(7):11751193. doi:10.1016/S0016-7037(98)00047-7

Bindeman IN, Leonov VL, Izbekov PE, Ponomareva VV, Watts KE, Shipley NK, Perepelov AB, Bazanova LI, Jicha BR, Singer BS, Schmitt AK, Portnyagin MV, Chen CH (2010) Large-volume silicic volcanism in Kamchatka: $\mathrm{Ar}-\mathrm{Ar}$ and $\mathrm{U}-\mathrm{Pb}$ ages, isotopic, and geochemical characteristics of major pre-Holocene caldera-forming eruptions. J Volcanol Geotherm Res 189(1-2):57-80. doi:10.1016/ j.jvolgeores.2009.10.009

Bird P (2003) An updated digital model of plate boundaries. Geochem Geophys Geosyst 4(3):1027. doi:10.1029/2001GC000252

Bohrson WA, Spera FJ (2001) Energy-constrained open-system magmatic processes II: application of energy-constrained assimilation-fractional crystallization (EC-AFC) model to magmatic systems. J Petrol 42(5):1019-1041. doi:10.1093/petrology/42.5.1019

Braitseva OA, Melekestsev IV, Ponomareva VV, Sulerzhitsky LD (1995) Ages of calderas, large explosive craters and active volcanoes in the Kuril-Kamchatka region, Russia. Bull Volcanol 57(6):383-402. doi: 10.1007/BF00300984

Branney M, Acocella V (2015) Chapter 16 - Calderas. In: Sigurdsson H (ed) The encyclopedia of volcanoes, 2 nd edn. Academic, Amsterdam, pp 299-315. doi:10.1016/B978-0-12-385938-9. 00016-X

Brophy $\mathrm{J}$ (2008) A study of rare earth element (REE)- $\mathrm{SiO}_{2}$ variations in felsic liquids generated by basalt fractionation and amphibolite melting: a potential test for discriminating between the two different processes. Contrib Mineral Petrol 156(3):337-357. doi:10.1007/ s00410-008-0289-x

Buddington AF, Lindsley DH (1964) Iron-titanium oxide minerals and synthetic equivalents. J Petrol 5(2):310-357. doi:10.1093/petrology/ 5.2 .310

Budnikov BA (1988) The eruption of Gorely volcano in April 1986. J Volcanol Seismol 4:99-103 (in Russian)

Bulin NK (1977) Deep structure of Kamchatka and Kuril Islands from seismic data. Soviet Geol 5:140-148 (in Russian)

Chappell BW, White AJR (2001) Two contrasting granite types: 25 years later. Aust J Earth Sci 48(4):489-499. doi:10.1046/j.1440-0952. 2001.00882.x

Chashchin AA, Martynov YA (2011) Petrology of Gorely and Mutnovsky volcanoes rocks (Southern Kamchatka). Dalnauka, Vladivostok, p 270 (in Russian)

Chashchin AA, Martynov YA, Perepelov AB, Ekimova NI, Vladimirova TP (2011) Physical and chemical conditions of the formation and evolution of late pleistocene-holocene magmas of the Gorely and Mutnovsky volcanoes, southern Kamchatka. Russ J Pac Geol 5(4): 348-367. doi:10.1134/S1819714011040038

Churikova T, Dorendorf F, Worner G (2001) Sources and fluids in the mantle wedge below Kamchatka, evidence from across-arc geochemical variation. J Petrol 42(8):1567-1593. doi:10.1093/ petrology/42.8.1567

Danyushevsky LV (2001) The effect of small amounts of $\mathrm{H}_{2} \mathrm{O}$ on crystallisation of mid-ocean ridge and backarc basin magmas. $\mathrm{J}$ Volcanol Geotherm Res 110(3-4):265-280. doi:10.1016/S03770273(01)00213-X

Danyushevsky LV, Plechov P (2011) Petrolog3: integrated software for modeling crystallization processes. Geochem Geophys Geosyst 12(7), Q07021. doi:10.1029/2011GC003516

Danyushevsky LV, Sobolev AV, Dmitriev LV (1996) Estimation of the pressure of crystallization and $\mathrm{H}_{2} \mathrm{O}$ content of MORB and $\mathrm{BABB}$ glasses: calibration of an empirical technique. Mineral Petrol 57(34):185-204. doi:10.1007/BF01162358

Davidson J, de Silva S (2000) Composite volcanoes. In: Sigurdsson H (ed) The encyclopedia of volcanoes. Academic Press, p 663-682

DeMets C, Gordon RG, Argus DF, Stein S (1990) Current plate motions. Geophys J Int 101(2):425-478. doi:10.1111/j.1365-246X.1990. tb06579.x 
DePaolo DJ (1981) Trace element and isotopic effects of combined wallrock assimilation and fractional crystallization. Earth Planet Sci Lett 53(2):189-202. doi:10.1016/0012-821X(81)90153-9

Donovan JJ (2012) Probe for EPMA: acquisition, automation and analysis, Enterpriseth edn. Probe Software, Inc., Eugene

Duggen S, Portnyagin M, Baker J, Ulfbeck D, Hoernle K, GarbeSchönberg D, Grassineau N (2007) Drastic shift in lava geochemistry in the volcanic-front to rear-arc region of the Southern Kamchatkan subduction zone: evidence for the transition from slab surface dehydration to sediment melting. Geochim Cosmochim Acta 71(2):452-480. doi:10.1016/j.gca.2006.09.018

Eichelberger JC (1978) Andesitic volcanism and crustal evolution. Nature 275(5675):21-27. doi:10.1038/275021a0

Eichelberger JC (1980) Vesiculation of mafic magma during replenishment of silicic magma reservoirs. Nature 288(5790):446-450. doi: 10.1038/288446a0

Fedotov SA, Masurenkov YP (eds) (1991) Active volcanoes of Kamchatka. Nauka, Moscow

Feig S, Koepke J, Snow J (2006) Effect of water on tholeiitic basalt phase equilibria: an experimental study under oxidizing conditions. Contrib Mineral Petrol 152(5):611-638. doi:10.1007/s00410-006$0123-2$

Ford CE, Russel DG, Graven JA, Fisk MR (1983) Olivine-liquid equilibria: temperature, pressure and composition dependence of the crystal/liquid cation partition coefficients for $\mathrm{Mg}, \mathrm{Fe} 2+, \mathrm{Ca}$ and Mn. J Petrol 24(3):256-266. doi:10.1093/petrology/24.3.256

Gavrilenko M, Herzberg C, Vidito C, Carr MJ, Tenner TJ, Ozerov AY (2016) A preliminary olivine geohygrometer and its application to subduction zone magmatism. J Petrol. (in review)

Gill JB (1981) Orogenic andesites and plate tectonics. Springer-Verlag. doi:10.1007/978-3-642-68012-0

Ginibre C, Wörner G (2007) Variable parent magmas and recharge regimes of the Parinacota magma system (N. Chile) revealed by Fe, $\mathrm{Mg}$ and $\mathrm{Sr}$ zoning in plagioclase. Lithos 98(1-4):118-140. doi:10. 1016/j.lithos.2007.03.004

Gorbach NV, Portnyagin MV (2011) Geology and petrology of the lava complex of Young Shiveluch Volcano, Kamchatka. Petrology 19(2): 134-166. doi:10.1134/s0869591111020068

Gorbach N, Portnyagin M, Tembrel I (2013) Volcanic structure and composition of Old Shiveluch volcano, Kamchatka. J Volcanol Geotherm Res 263:193-208. doi:10.1016/j.jvolgeores.2012.12.012

Gorbatov A, Kostoglodov V, Suárez G, Gordeev E (1997) Seismicity and structure of the Kamchatka subduction zone. J Geophys Res: Solid Earth 102(B8):17883-17898. doi:10.1029/96JB03491

Gorbatov A, Domínguez J, Suárez G, Kostoglodov V, Zhao D, Gordeev E (1999) Tomographic imaging of the P-wave velocity structure beneath the Kamchatka peninsula. Geophys J Int 137(2):269-279. doi: 10.1046/j.1365-246X.1999.t01-1-00801.x

Grove T, Elkins-Tanton L, Parman S, Chatterjee N, Müntener O, Gaetani G (2003) Fractional crystallization and mantle-melting controls on calc-alkaline differentiation trends. Contrib Mineral Petrol 145(5): 515-533. doi:10.1007/s00410-003-0448-z

Gudmundsson A (2011) Deflection of dykes into sills at discontinuities and magma-chamber formation. Tectonophysics 500(1-4):50-64. doi:10.1016/j.tecto.2009.10.015

Herzberg C, Vidito C, Starkey N (2016) Nickel - cobalt contents of olivine record origins of mantle peridotite and related rocks. Am Mineral. (accepted, in press)

Hildreth W, Moorbath S (1988) Crustal contributions to arc magmatism in the Andes of Central Chile. Contrib Mineral Petrol 98(4):455489. doi:10.1007/BF00372365

Ishikawa T, Tera F, Nakazawa T (2001) Boron isotope and trace element systematics of the three volcanic zones in the Kamchatka arc. Geochim Cosmochim Acta 65(24):4523-4537. doi:10.1016/ S0016-7037(01)00765-7
Ivanov BV, Droznin VA, Vakin EA, Ivanov VV, Ovsyannikov AA, Razina AA (1988) Eruption of Gorely volcano in 1985. J Volcanol Seismol 4:93-98 (in Russian)

Iwasaki T, Levin V, Nikulin A, Iidaka T (2013) Constraints on the Moho in Japan and Kamchatka. Tectonophysics 609:184-201. doi:10. 1016/j.tecto.2012.11.023

Izbekov P, Gardner JE, Eichelberger JC (2004) Comagmatic granophyre and dacite from Karymsky volcanic center, Kamchatka: experimental constraints for magma storage conditions. J Volcanol Geotherm Res 131(1-2):1-18. doi:10.1016/S03770273(03)00312-3

Jarosewich E, Nelen JA, Norberg JA (1980) Reference samples for electron microprobe analysis. Geostand Newslett 4(1):43-47. doi:10. 1111/j.1751-908X.1980.tb00273.x

Kelley KA, Cottrell E (2009) Water and the oxidation state of subduction zone magmas. Science 325(5940):605-607. doi:10.1126/science. 1174156

Kinzler RJ, Grove TL, Recca SI (1990) An experimental study on the effect of temperature and melt composition on the partitioning of nickel between olivine and silicate melt. Geochimica Et Cosmochimica Acta 54(5):1255-1265. doi:10.1016/00167037(90)90151-a

Kirsanov IT (1964) State of the volcanoes Gorely and Mutnovsky for the period from October 1959 to October 1960. Bull Volcano Station 35:34-43 (in Russian)

Kirsanov IT (1985) Gorely volcano, its geological structure, the last eruptions, and composition of the products. In: (1985) Volcanic activity, its mechanism, the link with geodynamics, eruptions and earthquakes forecast, Petropavlovsk-Kamchatsky, p 32-33. (in Russian)

Kirsanov IT, Fedorov MV (1964) Ignimbrites of Gorely volcano. In (1964) Problems of volcanism. Proceedings of the II USSR Volcanological Meeting. Petropavlovsk-Kamchatsky, p 45-47. (in Russian)

Kirsanov IT, Melekescev IV (1991) Gorely volcano. In: Fedotov SA, Masurenkov YP (eds) Active volcanoes of Kamchatka. Nauka, Moscow, pp 294-317

Kirsanov IT, Ozerov AY (1983) The products composition and energetic effect of the Gorely volcano eruption in 1980-1981. J Volcanol Seismol 1:25-42 (in Russian)

Kirsanov IT, Ogorodov NV, Chirkov AM (1964) State Mutnovsky and Gorely volcanoes between November 1960 and June 1961. Bull Volcano Station 36:39-47 (in Russian)

Kress VC, Carmichael ISE (1988) Stoichiometry of the iron oxidation reaction in silicate melts. Am Mineral 73(11-12):1267-1274

Kulakov VS (1936) Volcanic observations in Kamchatka. Priroda 10:5354 (in Russian)

Langmuir CH, Vocke RD Jr, Hanson GN, Hart SR (1978) A general mixing equation with applications to Icelandic basalts. Earth Planet Sci Lett 37(3):380-392. doi:10.1016/0012-821X(78)90053-5

Le Bas MJ, Le Maitre RW, Streckeisen A, Zanettin B (1986) A chemical classification of volcanic rocks based on the total alkali-silica diagram. J Petrol 27(3):745-750. doi:10.1093/petrology/27.3.745

Le Maitre RW, Bateman P, Dudek A, Keller J, Lameyre J, Le Bas MJ, Sabine PA, Schmid R, Sorensen H, Streckeisen A, Woolley AR, Zanettin B (1989) A classification of igneous rocks and glossary of terms: recommendations of the international Union Of Geological Sciences Subcommission on the Systematics of Igneous Rocks. Blackwell Scientific, Oxford

Lee C-TA, Luffi P, Plank T, Dalton H, Leeman WP (2009) Constraints on the depths and temperatures of basaltic magma generation on Earth and other terrestrial planets using new thermobarometers for mafic magmas. Earth Planet Sci Lett 279(1-2):20-33. doi:10.1016/j.epsl. 2008.12.020

Lee C-TA, Luffi P, Chin EJ, Bouchet R, Dasgupta R, Morton DM, Le Roux V, Q-z Y, Jin D (2012) Copper systematics in arc magmas and 
implications for crust-mantle differentiation. Science 336(6077):6468. doi:10.1126/science.1217313

Lee C-TA, Lee TC, Wu C-T (2014) Modeling the compositional evolution of recharging, evacuating, and fractionating (REFC) magma chambers: implications for differentiation of arc magmas. Geochim Cosmochim Acta 143:8-22. doi:10.1016/j.gca.2013.08.009

Lees JM (1992) The magma system of Mount St. Helens: non-linear high-resolution P-wave tomography. J Volcanol Geotherm Res 53(1-4):103-116. doi:10.1016/0377-0273(92)90077-Q

Levin V, Park J, Brandon M, Lees J, Peyton V, Gordeev E, Ozerov A (2002) Crust and upper mantle of Kamchatka from teleseismic receiver functions. Tectonophysics 358(1-4):233-265. doi:10.1016/ s0040-1951(02)00426-2

Levin V, Droznina S, Gavrilenko M, Carr MJ, Senyukov S (2014) Seismically active subcrustal magma source of the Klyuchevskoy volcano in Kamchatka, Russia. Geology 42(11):983-986. doi:10. 1130/g35972.1

Lipman PW (1997) Subsidence of ash-flow calderas: relation to caldera size and magma-chamber geometry. Bull Volcanol 59(3):198-218. doi: $10.1007 / \mathrm{s} 004450050186$

Longpré M-A, Troll VR, Walter TR, Hansteen TH (2009) Volcanic and geochemical evolution of the Teno massif, Tenerife, Canary Islands: some repercussions of giant landslides on ocean island magmatism. Geochem Geophys Geosyst 10(12). doi:10.1029/2009GC002892

Manconi A, Longpré M-A, Walter TR, Troll VR, Hansteen TH (2009) The effects of flank collapses on volcano plumbing systems. Geology 37(12):1099-1102. doi:10.1130/g30104a.1

Menand T (2008) The mechanics and dynamics of sills in layered elastic rocks and their implications for the growth of laccoliths and other igneous complexes. Earth Planet Sci Lett 267(1-2):93-99. doi:10. 1016/j.eps1.2007.11.043

Mironov NL, Portnyagin MV (2011) $\mathrm{H}_{2} \mathrm{O}$ and $\mathrm{CO}_{2}$ in parental magmas of Kliuchevskoi volcano inferred from study of melt and fluid inclusions in olivine. Russ Geol Geophys 52(11):1353-1367. doi:10. 1016/j.rgg.2011.10.007

Mironov N, Portnyagin M, Botcharnikov R, Gurenko A, Hoernle K, Holtz F (2015) Quantification of the $\mathrm{CO}_{2}$ budget and $\mathrm{H}_{2} \mathrm{O}-\mathrm{CO}_{2}$ systematics in subduction-zone magmas through the experimental hydration of melt inclusions in olivine at high $\mathrm{H}_{2} \mathrm{O}$ pressure. Earth Planet Sci Lett 425:1-11. doi:10.1016/j.epsl.2015.05.043

Miyashiro A (1974) Volcanic rock series in island arcs and active continental margins. Am J Sci 274(4):321-355. doi:10.2475/ajs.274.4. 321

Morimoto N, Fabries J, Ferguson AK, Ginzburg IV, Ross M, Seifert FA, Zussman J, Aoki K, Gottardi G (1988) Nomenclature of pyroxenes. Am Mineral 73(9-10):1123-1133

Müller RD, Sdrolias M, Gaina C, Roest WR (2008) Age, spreading rates, and spreading asymmetry of the world's ocean crust. Geochem Geophys Geosyst 9(4). doi:10.1029/2007GC001743

Nikulin A, Levin V, Carr M, Herzberg C, West M (2012) Evidence for two upper mantle sources driving volcanism in Central Kamchatka. Earth Planet Sci Lett 321-322:14-19. doi:10.1016/j.epsl.2011.12. 039

Norman MD, Pearson NJ, Sharma A, Griffin WL (1996) Quantitative analysis of trace elements in geological materials by laser ablation ICPMS: instrumental operating conditions and calibration values of NIST glasses. Geostand Newslett 20(2):247-261. doi:10.1111/j. 1751-908X.1996.tb00186.x

Novograblenov PT (1932) Catalogue of volcanoes of Kamchatka. News of the state geographical society 64(1):88-99. (in Russian)

Oldenburg CM, Spera FJ, Yuen DA, Sewell G (1989) Dynamic mixing in magma bodies: theory, simulations, and implications. J Geophys Res: Solid Earth 94(B7):9215-9236. doi:10.1029/ JB094iB07p09215
O'Neill HS, Jenner FE (2012) The global pattern of trace-element distributions in ocean floor basalts. Nature 491(7426):698-704. doi:10. 1038/nature 11678

Orihashi Y, Hirata T (2003) Rapid quantitative analysis of Y and REE abundances in XRF glass bead for selected GSJ reference rock standards using Nd-YAG $266 \mathrm{~nm}$ UV laser ablation ICP-MS. Geochem J 37(3):401-412. doi:10.2343/geochemj.37.401

Ozerov AY (2000) The evolution of high-alumina basalts of the Klyuchevskoy volcano, Kamchatka, Russia, based on microprobe analyses of mineral inclusions. J Volcanol Geotherm Res 95(1-4): 65-79. doi:10.1016/s0377-0273(99)00118-3

Perugini D, Poli G (2012) The mixing of magmas in plutonic and volcanic environments: analogies and differences. Lithos 153:261-277. doi:10.1016/j.lithos.2012.02.002

Petford N, Atherton M (1996) Na-rich partial melts from newly underplated basaltic crust: the Cordillera Blanca Batholith, Peru. J Petrol 37(6):1491-1521. doi:10.1093/petrology/37.6.1491

Pinel V, Jaupart C (2000) The effect of edifice load on magma ascent beneath a volcano. Philosophical transactions of the Royal Society of London A: mathematical. Phys Eng Sci 358(1770):1515-1532. doi:10.1098/rsta.2000.0601

Pinel V, Jaupart C (2003) Magma chamber behavior beneath a volcanic edifice. J Geophys Res: Solid Earth 108(B2). doi:10.1029/ 2002JB001751

Pinel V, Jaupart C (2005) Some consequences of volcanic edifice destruction for eruption conditions. J Volcanol Geotherm Res 145(1-2):6880. doi:10.1016/j.jvolgeores.2005.01.012

Plank T, Kelley KA, Zimmer MM, Hauri EH, Wallace PJ (2013) Why do mafic arc magmas contain $\sim 4 \mathrm{wt} \%$ water on average? Earth Planet Sci Lett 364:168-179. doi:10.1016/j.epsl.2012.11.044

Portnyagin M, Bindeman I, Hoernle K, Hauff F (2007) Geochemistry of primitive lavas of the Central Kamchatka depression: magma generation at the edge of the pacific plate. In: Volcanism and subduction: the Kamchatka region. American Geophysical Union, p 199 239. doi:10.1029/172GM16

Portnyagin M, Hoernle K, Plechov P, Mironov N, Khubunaya S (2007b) Constraints on mantle melting and composition and nature of slab components in volcanic arcs from volatiles $\left(\mathrm{H}_{2} \mathrm{O}, \mathrm{S}, \mathrm{Cl}, \mathrm{F}\right)$ and trace elements in melt inclusions from the Kamchatka Arc. Earth Planet Sci Lett 255(1-2):53-69. doi:10.1016/j.epsl.2006.12.005

Portnyagin M, Duggen S, Hauff F, Mironov N, Bindeman I, Thirlwall M, Hoernle K (2015) Geochemistry of the late Holocene rocks from the Tolbachik volcanic field, Kamchatka: quantitative modelling of subduction-related open magmatic systems. J Volcanol Geotherm Res 307:133-155. doi:10.1016/j.jvolgeores.2015.08.015

Presley TK, Sinton JM, Pringle M (1997) Postshield volcanism and catastrophic mass wasting of the Waianae Volcano, Oahu, Hawaii. Bull Volcanol 58(8):597-616. doi:10.1007/s004450050165

Rapp RP, Watson EB (1995) Dehydration melting of metabasalt at 8-32 kbar: implications for continental growth and crust-mantle recycling. J Petrol 36(4):891-931. doi:10.1093/petrology/36.4.891

Righter K, Leeman WP, Hervig RL (2006) Partitioning of Ni, Co and V between spinel-structured oxides and silicate melts: importance of spinel composition. Chem Geol 227(1-2):1-25. doi:10.1016/j. chemgeo.2005.05.011

Rogers N (2015) Chapter 4 - the composition and origin of magmas. In: Sigurdsson $\mathrm{H}$ (ed) The encyclopedia of volcanoes, 2nd edn. Academic, Amsterdam, pp 93-112. doi:10.1016/B978-0-12385938-9.00004-3

Ruprecht P, Plank T (2013) Feeding andesitic eruptions with a high-speed connection from the mantle. Nature 500(7460):68-72. doi:10.1038/ nature 12342

Ruscitto DM, Wallace PJ, Johnson ER, Kent AJR, Bindeman IN (2010) Volatile contents of mafic magmas from cinder cones in the Central Oregon High Cascades: implications for magma formation and 
mantle conditions in a hot arc. Earth Planet Sci Lett 298(1-2):153161. doi:10.1016/j.eps1.2010.07.037

Ruscitto DM, Wallace PJ, Cooper LB, Plank T (2012) Global variations in $\mathrm{H}_{2} \mathrm{O} / \mathrm{Ce}: 2$. Relationships to arc magma geochemistry and volatile fluxes. Geochem Geophys Geosyst 13(3):Q03025. doi:10.1029/ 2011GC003887

Ryan WBF, Carbotte SM, Coplan JO, O'Hara S, Melkonian A, Arko R, Weissel RA, Ferrini V, Goodwillie A, Nitsche F, Bonczkowski J, Zemsky R (2009) Global multi-resolution topography synthesis. Geochem Geophys Geosyst 10(3):Q03014. doi:10.1029/ 2008GC002332

Sakuyama M (1979) Evidence of magma mixing: petrological study of Shirouma-Oike calc-alkaline andesite volcano, Japan. J Volcanol Geotherm Res 5(1-2):179-208. doi:10.1016/0377-0273(79) 90040-4

Scandone R, Malone SD (1985) Magma supply, magma discharge and readjustment of the feeding system of Mount St. Helens during 1980. J Volcanol Geotherm Res 23(3):239-262. doi:10.1016/ 0377-0273(85)90036-8

Seligman A, Bindeman I, Jicha B, Ellis B, Ponomareva V, Leonov V (2014) Multi-cyclic and isotopically diverse silicic magma generation in an arc volcano: Gorely Eruptive Center, Kamchatka, Russia. J Petrol 55(8):1561-1594. doi:10.1093/petrology/egu034

Selyangin OB (1993) New data on Mutnovsky volcano: structure, evolution and prediction. J Volcanol Seismol 1:17-35 (in Russian)

Selyangin OB (2009) Wonderful world of Mutnovsky and Gorely volcanoes: volcanologic and traveller's guide. Hold. komp. "Novaya kniga", Petropavlovsk-Kamchatsky, p 108

Selyangin OB, Ponomareva VV (1999) Gorelovsky volcanic center, Southern Kamchatka: structure and evolution. J Volcanol Seismol 2:3-23 (in Russian)

Shipman JS, Izbekov P, Gavrilenko MG (2011), Petrologic insights into magma system response to edifice collapse, Abstract V21E-2540 presented at 2011 Fall Meeting, AGU, San Francisco

Sigmundsson F, Hreinsdottir S, Hooper A, Arnadottir T, Pedersen R, Roberts MJ, Oskarsson N, Auriac A, Decriem J, Einarsson P, Geirsson H, Hensch M, Ofeigsson BG, Sturkell E, Sveinbjornsson H, Feigl KL (2010) Intrusion triggering of the 2010 Eyjafjallajokull explosive eruption. Nature 468(7322):426-430. doi:10.1038/ nature09558

Simakin AG, Bindeman IN (2012) Remelting in caldera and rift environments and the genesis of hot, "recycled" rhyolites. Earth Planet Sci Lett 337-338:224-235. doi:10.1016/j.epsl.2012.04.011

Smith DR, Leeman WP (1987) Petrogenesis of Mount St. Helens dacitic magmas. J Geophys Res: Solid Earth 92(B10):10313-10334. doi: 10.1029/JB092iB10p10313

Sobolev AV, Hofmann AW, Kuzmin DV, Yaxley GM, Arndt NT, Chung S-L, Danyushevsky LV, Elliott T, Frey FA, Garcia MO, Gurenko AA, Kamenetsky VS, Kerr AC, Krivolutskaya NA, Matvienkov VV, Nikogosian IK, Rocholl A, Sigurdsson IA, Sushchevskaya NM, Teklay M (2007) The amount of recycled crust in sources of mantle-derived melts. Science 316(5823):412-417. doi:10.1126/ science. 1138113

Spera FJ, Bohrson WA (2001) Energy-constrained open-system magmatic processes I: general model and energy-constrained assimilation and Fractional Crystallization (EC-AFC) formulation. J Petrol 42(5):999-1018. doi:10.1093/petrology/42.5.999

Steblov GM, Kogan MG, King RW, Scholz CH, Bürgmann R, Frolov DI (2003) Imprint of the North American plate in Siberia revealed by GPS. Geophys Res Lett 30(18):1924. doi:10.1029/2003GL017805

Stern RJ (2002) Subduction zones. Rev Geophys 40(4):1012. doi:10. 1029/2001RG000108

Straub SM, LaGatta AB, Martin-Del Pozzo AL, Langmuir CH (2008) Evidence from high-Ni olivines for a hybridized peridotite/ pyroxenite source for orogenic andesites from the central Mexican Volcanic Belt. Geochem Geophys Geosyst 9(3):Q03007. doi:10. 1029/2007GC001583

Sun S-s, McDonough WF (1989) Chemical and isotopic systematics of oceanic basalts: implications for mantle composition and processes. Geol Soc Lond, Spec Publ 42(1):313-345. doi:10.1144/gsl.sp.1989. 042.01.19

Svyatlovsky AE (1956) South Bystrinsky range on the Kamchatka Peninsula. Proc Lab Volcanol (12):110-190. (in Russian)

Tepper J, Nelson B, Bergantz G, Irving A (1993) Petrology of the Chilliwack batholith, North Cascades, Washington: generation of calc-alkaline granitoids by melting of mafic lower crust with variable water fugacity. Contrib Mineral Petrol 113(3):333-351. doi:10. 1007/BF00286926

Tibaldi A (2004) Major changes in volcano behaviour after a sector collapse: insights from Stromboli, Italy. Terra Nov. 16(1):2-8. doi:10. 1046/j.1365-3121.2003.00517.x

Tolstykh ML, Naumov VB, Gavrilenko MG, Ozerov AY, Kononkova NN (2012) Chemical composition, volatile components, and trace elements in the melts of the Gorely volcanic center, southern Kamchatka: evidence from inclusions in minerals. Geochem Int 50(6):522-550. doi:10.1134/S0016702912060079

Toplis MJ (2005) The thermodynamics of iron and magnesium partitioning between olivine and liquid: criteria for assessing and predicting equilibrium in natural and experimental systems. Contrib Mineral Petrol 149(1):22-39. doi:10.1007/s00410-0040629-4

Vidito C, Herzberg C, Gazel E, Geist D, Harpp K (2013) Lithological structure of the Galápagos Plume. Geochem Geophys Geosyst 14(10):4214-4240. doi:10.1002/ggge.20270

Vlodavets VI (1957) Gorely ridge. Bulletin of volcano stations (25):6870. (in Russian)

Volynets ON, Babanskii AD, Gol'tsman YV (2000) Variations in isotopic and trace-element composition of lavas from volcanoes of the Northern group, Kamchatka, in relation to specific features of subduction. Geochem Int 38(10):974-989

Volynets A, Churikova T, Wörner G, Gordeychik B, Layer P (2010) Mafic Late Miocene-Quaternary volcanic rocks in the Kamchatka back arc region: implications for subduction geometry and slab history at the Pacific-Aleutian junction. Contrib Mineral Petrol 159(5): 659-687. doi:10.1007/s00410-009-0447-9

Wallace PJ (2005) Volatiles in subduction zone magmas: concentrations and fluxes based on melt inclusion and volcanic gas data. J Volcanol Geotherm Res 140(1-3):217-240. doi:10.1016/j.jvolgeores.2004. 07.023

Wan Z, Coogan LA, Canil D (2008) Experimental calibration of aluminum partitioning between olivine and spinel as a geothermometer Am Mineral 93(7):1142-1147. doi:10.2138/am.2008.2758

Yu Z, Robinson P, McGoldrick P (2001) An evaluation of methods for the chemical decomposition of geological materials for trace element determination using ICP-MS. Geostand Newslett 25(2-3):199 217. doi:10.1111/j.1751-908X.2001.tb00596.x

Zavaritsky AN, Piip BI, Gorshkov GS (1954) The study of volcanoes of Kamchatka. Proc Lab Volcanol (8):18-57. (in Russian)

Zimmer MM, Plank T, Hauri EH, Yogodzinski GM, Stelling P, Larsen J, Singer B, Jicha B, Mandeville C, Nye CJ (2010) The role of water in generating the calc-alkaline trend: new volatile data for Aleutian magmas and a new tholeiitic index. J Petrol 51(12):2411-2444. doi:10.1093/petrology/egq062

Zlobin TK, Gureev RG, Zlobina LM (2005) Deep structure of southwestern Kamchatka from the data of the earthquake converted wave method. Russ J Pac Geol 24(1):14-24 (in Russian) 